\title{
Política econômica, instituições e classes sociais: os governos do Partido dos Trabalhadores no Brasil *
}

\author{
Pedro Cezar Dutra Fonseca ${ }^{* * * * *}$ \\ Marcelo Arend ${ }^{* * * *}$ \\ Glaison Augusto Guerrero ${ }^{* * * * *}$
}

\begin{abstract}
Resumo
A partir de uma perspectiva da Economia Política, o artigo analisa os governos de Lula e Dilma Rousseff, enfocando o relacionamento entre a política macroeconômica e seus condicionantes políticos, econômicos e sociais. Mostra que tais governos executaram com relativo êxito um projeto de redistribuição de renda, porém, ao contrário de parte da literatura, defende que os mesmos não podem ser caracterizados, a rigor, nem como neoliberais ou, tampouco, como desenvolvimentistas. Defende, ainda, a hipótese de que a "nova matriz macroeconômica" do governo Rousseff representou mais do que mera alteração na política econômica: constituiu-se em ponto de inflexão nos governos petistas, pois significou o desfazimento de um pacto de coalizão de classes firmado por Lula com segmentos empresariais, o qual os respaldava desde a "Carta ao Povo Brasileiro" (2002). A partir de 2008, a crise econômica internacional, o processo de desindustrialização em marcha e um conjunto de condições permissivas evidenciaram os limites da coalizão em vigor, dificultando a continuidade do projeto redistributivo.
\end{abstract}

Palavras-chave: Governo Lula, Governo Rousseff, Desenvolvimentismo, Economia brasileira.

\section{Abstract}

Economic policy, institutions and social classes: an analysis of the workers' party governments in Brazil (2002-2016)

From a political economy perspective, this paper analyzes the Lula and Rousseff administrations in Brazil, focusing on the relationship between macroeconomic policy and its political, economic and social constraints. It shows that both administrations implemented relatively successful projects of income redistribution. However, contradicting part of the literature, the paper advocates that they cannot be characterized as neoliberal nor developmentalist. It also advocates that the "new macroeconomic matrix", set forward by the Rousseff administration, represented more than a mere change in economic policy: it constituted an inflection point in the Workers' Party (PT) administrations, since it meant the undoing of a "classes coalition pact" agreed between Lula and businesses segments, which supported PT's governments since the "Letter to the Brazilian People" (2002). As of 2008, the conjunction of a world economic crises, ongoing deindustrialization and a set of permissive conditions exposed the limits of the coalition in force, hindering the continuity of the redistributive project.

Keywords: Lula Administration, Rousseff Administration, Developmentalism, Brazilian economy.

JEL E6, O5, N1.

* Artigo recebido em 14 de março de 2019 e aprovado em 20 de dezembro de 2019. Trata-se de uma versão ampliada e modificada de "Growth, distribution and crisis: the administrations of workers' party in Brasil", aprovado para publicação em Latin American Perspectives.

${ }^{* *}$ Professor Titular do Departamento de Economia e Relações Internacionais da Universidade Federal do Rio Grande do Sul (UFRGS), Porto Alegre, RS, Brasil. E-mail: pedro.fonseca@ufrgs.br. ORCID: https://orcid.org/0000-0002-3814-9578.

${ }_{* * *}^{*}$ Pesquisador do Conselho Nacional de Desenvolvimento Científico e Tecnológico (CNPq), Brasília, DF, Brasil.

${ }^{* * * *}$ Professor Associado do Departamento de Economia e Relações Internacionais da Universidade Federal de Santa Catarina (UFSC), Florianópolis, SC, Brasil. E-mail: marcelo.arend@ufsc.br. ORCID: https://orcid.org/0000-0002-5748-9690.

${ }^{* * * * * *}$ Professor Adjunto do Departamento de Economia e Relações Internacionais da Universidade Federal do Rio Grande do Sul (UFRGS), Porto Alegre, RS, Brasil. E-mail: glaison.guerrero@ufrgs.br. ORCID: https://orcid.org/0000-0002-4802-973X. 


\section{Introdução}

O tema deste artigo é a política econômica dos governos de Lula (2003-2010) e Rousseff (2011-2016), a qual é objeto de intensa controvérsia na literatura. Esta diz respeito não só a seu caráter ortodoxo ou heterodoxo, como a seus compromissos e desempenho em variáveis relevantes, tais como distribuição de renda e desindustrialização, além de se estender aos segmentos sociais que respaldaram tais governos e que, posteriormente, formaram fileiras a favor ou contra o impeachment de Rousseff. Há certo consenso de que a política econômica do primeiro governo de Lula, executada por Antônio Palocci, no Ministério da Fazenda, e Henrique Meirelles, no Banco Central, representou forte continuidade com a de Fernando Henrique Cardoso. Na prática, a manutenção do regime de inflação como diretriz básica das políticas macroeconômicas, viabilizado por taxas de juros elevadas, superávit primário no orçamento público e câmbio apreciado. Tais políticas rompiam com bandeiras históricas do Partido dos Trabalhadores. Vários autores as associaram à ortodoxia e a neoliberalismo (Paulani, 2003, 2005, 2007; Paula, 2005; Borges Neto in Paula, 2005; Paulani in Sicsú et al., 2005; Assis in Sicsú et al., 2005; Carvalho, 2007; Gonçalves, 2012).

Por outro lado, as taxas de crescimento maiores verificadas no governo Lula, se comparadas ao período de Cardoso, assim como a ampliação das políticas de inclusão social e a melhoria do índice de Gini, levaram outros autores a questionar tais interpretações. Muitos defenderam que a política econômica mais lembrava um retorno ao desenvolvimentismo, ideário associado historicamente ao processo de substituição de importações (1930-1980) e que teria sido abandonado pelos sucessivos governos a partir das duas últimas décadas do século XX. Dentre eles, podem-se citar, por exemplo: Belluzzo (2009), Novy (2009a), (2009b); Nakano, (2010); Cervo (2009); Herrlein, (2011); Cardoso Jr. (2011); Anderson, 2011; Bastos, 2012; Costa, 2015). Trabalhos posteriores, por outro lado, procuraram superar a polarização entre ortodoxia versus desenvolvimentismo. Erber (2011) assinalou que no governo Lula coexistiam duas "convenções" ou visões de mundo, uma "institucionalista restrita", de caráter mais ortodoxo, e outra denominada por ele de "neodesenvolvimentista", ambas com "núcleos duros analíticos distintos (...), portanto, ontologicamente conflitivas". Morais e Saad-Filho (2011), em linha semelhante, argumentaram que a política de Lula teria sido "híbrida", e que o mesmo chegou a implantar políticas próximas do "novo-desenvolvimentismo" formulado por Bresser-Pereira (2006; 2011). Já Fonseca, Cunha e Bichara (2013), defenderam que, embora houvesse aspectos tanto de ruptura como de continuidade com relação à política do governo de F. H. Cardoso, não havia razões suficientes para interpretá-la como um retorno ao desenvolvimentismo.

As polêmicas permanecem com relação à política econômica do governo Rousseff, até porque esta passou por várias alterações. Ao assumir, em janeiro de 2011, manteve Guido Mantega no Ministério da Fazenda - que substituíra Palocci em 2006 - e, de início, parecia tender à manutenção das mesmas diretrizes de política econômica dos governos de Lula. Todavia, a partir de agosto de 2011, houve uma mudança de orientação, muitas vezes conhecida como "nova matriz macroeconômica", fundamentalmente baixando as taxas de juros, apreciando o câmbio e flexibilizando o regime de metas de inflação. Nossa hipótese é que tal inflexão representou um desfazimento do pacto político de coalizão de classes estabelecido por Lula em 2002 através da 
"Carta ao Povo Brasileiro" e materializado em sua política econômica. Vários tópicos de pesquisa são daí decorrentes, e serão objeto deste artigo a seguir. Esses remetem a questões como: que fatores teriam levado Rousseff a dar guinada tão forte na política econômica, já que a anterior vinha sendo realizada com relativo êxito? A "nova matriz macroeconômica", mais próxima da heterodoxia, pode ser considerada como desenvolvimentista? Que setores empresariais respaldavam ou ajudaram a sustentar os governos petistas, e por que os mesmos teriam começado a deles se afastar a partir do primeiro mandato de Rousseff, fato que culminaria em seu impeachment?

Este artigo pretende ensaiar respostas a essas perguntas, com propósito de contribuir ao debate, embora reconheçamos seu caráter preliminar, pois a temática envolve programa de pesquisa ainda em andamento.

\section{Intervencionismo e desenvolvimentismo: o hard-core do conceito}

Para investigar se o governo Lula, bem como a mudança da política econômica de Rousseff de 2011 - a chamada "nova matriz macroeconômica" - podem ser associadas a desenvolvimentismo, é preciso esclarecer o que se entende por isso. $\mathrm{O}$ termo desenvolvimentismo é usado em muitos sentidos, de modo que tal ambiguidade favorece certa confusão conceitual. Talvez o maior problema seja confundir desenvolvimentismo com intervencionismo. Criou-se a tendência, principalmente entre autores afinados com o mainstream (e também na mídia brasileira), de se tratar qualquer medida de intervenção estatal como desenvolvimentismo e, por extensão, de forma pejorativa, como "populismo econômico". Entretanto, o desenvolvimentismo é uma forma peculiar de intervencionismo, não se confundindo como meras políticas reativas a crises, voltadas a contra-arrestar os ciclos econômicos, de cunho keynesiano, e até aceitas por modelos convencionais como IS-LM. Mais do que isso, representou historicamente um conjunto de medidas concatenadas para superar o subdesenvolvimento, portanto como uma estratégia ou guia de ação para superar uma condição histórico-estrutural. Destarte, o desenvolvimentismo, embora intervencionista (como a social democracia e o trabalhismo), não se confunde nem com as políticas anticíclicas keynesianas nem com socialismo, uma vez que não visa superar o capitalismo, pois se trata de projeto econômico assentado na industrialização dentro dos marcos institucionais deste sistema econômico. Em parte, tal posição já fora antecipada por Kalecki em artigo que compara a diferença entre as crises de demanda efetiva das economias desenvolvidas, quando o problema era diminuir a capacidade ociosa de um estoque de capital já existente, do problema crucial do subdesenvolvimento, que era crescer o próprio estoque de capital (Kalecki, 1977).

Aqui se parte da definição de Fonseca (2014, p. 60): “denomina-se desenvolvimentismo a política econômica formulada elou executada, de forma deliberada, por governos (nacionais ou subnacionais) para, através do crescimento da produção e da produtividade, sob a liderança do setor industrial, transformar a sociedade com vistas a alcançar fins desejáveis, destacadamente a superação de seus problemas econômicos e sociais, dentro dos marcos institucionais do sistema capitalista. " Este conceito foi construído através de metodologia inspirada em Sartori $(1970 ; 1984)$. Esta permite selecionar quais atributos fazem parte do 
"núcleo duro" ou "hard-core" do conceito, e aqueles que só aparecem em algumas experiências históricas suas. No caso, o hard-core compõe-se de três atributos: (a) a defesa de um projeto nacional, ou uma estratégia para o país, visando superar o subdesenvolvimento; (b) intervenção estatal, pois se entende que os mecanismos de mercado, por si só, não levariam ao resultado desejado; a estratégia precisa ser executada através de ações deliberadas; e (c) a industrialização, a qual abriria espaço para maior convergência de renda, produtividade e estágio tecnológico com os países mais ricos e desenvolvidos. Da metodologia se depreende que para determinada política econômica ser considerada desenvolvimentista precisa, necessariamente, preencher tais atributos, embora os conceitos não sejam fixados de uma vez para sempre, pois podem sofrer alterações na história, o que se denomina de "viagem conceitual" (traveling). Tal viagem se faz geralmente com a inclusão e exclusão de novos atributos, mas sem alterar o hard-core, o que poderia comprometer a precisão conceitual. Mas o recurso mostra que os conceitos não são construtos restritos ao "mundo das ideias", pois se alteram historicamente.

Nota-se que o conceito aqui usado impõe que o desenvolvimentismo depende de políticas deliberadas, conscientemente executadas com fim bem definido, tal como haviam antecipado tanto Prebisch (1961) como Furtado (1978). E que alguns atributos de caráter redistributivo, os quais são às vezes associados ao desenvolvimentismo - como distribuição de renda, redução das desigualdades, reforma agrária, ou mesmo democracia -, não fazem parte do hard-core conceitual, pois este, como não poderia deixar de ser, engloba o que é comum às várias experiências históricas. Ao contrário, a pesquisa mostrou que justamente tais atributos "sociais" são os que menos apareceram nas experiências desenvolvimentistas latinoamericanas. Vários governos tidos como desenvolvimentistas não só não redistribuíram renda como defenderam sua concentração; no campo político, muitos deles coexistiram com ditaduras. Outros, todavia, enfatizaram a reforma agrária e a redistribuição de renda como medidas importantes. Esses atributos não pertencem ao hard-core, portanto não podem servir como régua para definir se uma política econômica é ou não desenvolvimentista. Podem ocorrer em experiências históricas determinadas, dando-lhe especificidades, o que na literatura é chamado de "subtipo" (Weyland, 2001).

\section{Desindustrialização e distribuição de renda: o sentido da política econômica}

Retornando ao governo Lula, desde logo fica clara a ausência de um projeto que se poderia denominar de desenvolvimentista, mesmo de forma atualizada, ou seja, sem termos a pretensão de que se poderia repetir as experiências históricas da era da industrialização por substituição de importações (ISI). Em parte, isso se deve ao fato de o próprio PT nunca ter encampado programaticamente a defesa da industrialização como caminho para superação do subdesenvolvimento. Tal proposta era, via de regra, tida como superada, associada à etapa da ISI, ao populismo ou, ainda, ao regime militar e à concentração de renda do "milagre" de 19681973. O desenvolvimentismo trouxera como consequência um país industrializado, mas excludente; não construíra nem mesmo o "capitalismo nacional autônomo", pois a regra foi a 
associação/submissão ao capital estrangeiro. Deve-se ainda lembrar que o PT, desde sua fundação, contava com correntes socialistas e avessas à defesa de propostas econômicas "reformistas" ou "sociais-democratas", o que dificultou a formulação programática de um projeto econômico para o país, desenvolvimentista ou não. O ponto de encontro de todas essas correntes era a redistribuição de renda, a qual as unificava e da qual decorriam as propostas como aprofundamento da democracia, da participação popular e da reforma agrária.

Assim, havia um projeto para o país que supunha políticas econômicas interventoras para executá-lo, contemplando os atributos "a" e "b" do hard-core mencionado, mas não de crescimento ou desenvolvimento. Nossa hipótese é que a ausência de um projeto para reverter a desindustrialização do país é importante obstáculo para se caracterizar os governos do PT como desenvolvimentistas. Embora documentos como o Programa de Aceleração do crescimento (PAC), de 2007, os planos plurianuais (PPA) de 2004-2007 e 2008-2011 e o Plano Brasil Maior, de 2011, já no governo Rousseff, expressassem consciência tanto das desigualdades sociais como em relação ao processo de perda de posição da indústria, as medidas efetivamente tomadas foram basicamente com relação às primeiras. Por projeto, no caso, supõe-se não apenas declaração de intenções, mas pelo menos a tentativa de execução de medidas efetivas para viabilizá-las, a despeito de lograrem êxito ou não. No caso em pauta, nota-se que os resultados positivos na esfera da redistribuição de renda foram condicionados por políticas governamentais, ao contrário da desindustrialização. Esta se aprofundou ao longo do período, e não por falha na execução de políticas, mas por ausência de medidas efetivas, sem contar as dificuldades impostas pelas prioridades da política de estabilização (e que também era proposta deliberada dos próprios governos).

Sobre essa problemática, Nunes (2018), utilizando o mesmo conceito de desenvolvimentismo (Fonseca, 2014) para a análise do governo Lula, realiza a distinção entre medidas pretendidas, implantadas e resultados. Mostra que, embora haja documentos que expressem consciência sobre os problemas da indústria, não foram tomadas medidas para sua reversão. O trabalho também se apoia em Perissinotto (2014), o qual menciona três dimensões para verificar projeto de desenvolvimento e os limites para sua execução bem-sucedida: contextual, institucional e volitiva. Esta última aponta para a necessidade de uma elite modernizante disposta e apta para implementar as políticas desenvolvimentistas, como havia antecipado Hirschmann (1964).

Stumm, Nunes e Perissinotto (2019) mostram que ainda que os governos petistas se mostrassem favoráveis à utilização de políticas industriais, as medidas propostas estiveram longe de atingir os resultados pretendidos, alcançando menos da metade das metas estabelecidas. Objetivos fundamentais, não concretizados, diziam respeito a aspectos importantes como aumento das exportações, elevação dos investimentos, acréscimo de valor agregado e ampliação da escolaridade dos trabalhadores. Além desse balanço negativo, os autores mostram que as ações propostas não alteraram a estrutura industrial brasileira. 
Curado e Curado (2016) também ressaltam a inefetividade dos resultados das políticas industriais dos governos PT. Os autores mostram que as políticas industriais foram fortemente financiadas por gastos tributários e renúncias fiscais, que, surpreendentemente, foram destinados em maior quantidade a setores tradicionais da indústria nacional e não para atividades de inovação.

Sobre a especialização produtiva brasileira e seu padrão de investimento no século XXI, Schapiro (2013) evidencia a debilidade das políticas industriais nacionais, no sentido de não acarretarem mudança estrutural. Schapiro (2013, p. 31) mostra que as políticas adotadas pelo Plano Brasil Maior (PBM) do governo Dilma foram, em sua maioria, horizontais, e que "os programas parecem ter como referência a agenda do Custo Brasil, direcionando-se majoritariamente para a redução de encargos e barateamento de recursos financeiros para, desta maneira, aprimorar as condições de produção da malha industrial existente". O autor constata que, apesar de serem formuladas políticas industriais de cunho transformador (schumpeterianas), na prática o estado conseguiu somente minimizar falhas de mercado, com políticas de viés mais corretivo (ricardiano), de perfil mais semelhante à teoria de política industrial neoclássica. Assim, as estratégias adotadas pelo governo Dilma acabaram por manter a posição atual brasileira na divisão internacional do trabalho, pois incentivaram majoritariamente as atividades industriais tradicionais do país.

A análise do insucesso das políticas industriais dos governos petistas também é realizada por Bresser-Pereira, Nassif e Feijó (2016). Os autores enfatizam que não basta apenas a adoção de políticas industriais e tecnológicas consistentes, mas também que estas estejam estreitamente articuladas com o regime macroeconômico. Por regime macroeconômico Bresser-Pereira, Nassif e Feijó (2016) referem-se à adoção e implementação de políticas monetária, fiscal, cambial e salarial consistentes, cujo objetivo é não somente manter a estabilidade de preços, como também permitir que a economia consiga realizar seu potencial de crescimento econômico de forma sustentável. Para os autores, nenhuma dessas condições foi preenchida no Brasil nas últimas décadas. Daí a desindustrialização prematura, baixa produtividade e baixo crescimento observados no período dos governos PT.

O Gráfico 1 mostra que tal processo já se verificava desde a década de 1980, e mantevese e intensificou-se nos governos Lula e Rousseff. Lula iniciou em 2003 com 16,9\% de participação da indústria no PIB e Rousseff finalizou o ano de 2015 com 11,4\%, registrando ao final uma queda de 5,5\% da participação da indústria no PIB. Em relação à participação da indústria brasileira na indústria mundial, a queda registrada durante os governos PT foi mais intensa que a registrada no período 1990-2002, período geralmente associado à hegemonia de ideias neoliberais. Em 1990, a participação da indústria brasileira na indústria mundial era de 1,97\% e em 2002 foi de 1,90\%, registrando certa estabilidade. Porém, em 2015 a participação da indústria brasileira na indústria mundial retrocedeu para $1,43 \%$. Nestes termos, pode-se considerar que o processo de desindustrialização iniciado em meados dos anos 1980 e intensificado na década de 1990 manteve sua continuidade nos governos do PT, e que a relativa 
estagnação da indústria brasileira, em termos internacionais, foi até mesmo mais marcante nestes do que na década de 1990.

Gráfico 1

Participação percentual da indústria de transformação no PIB do Brasil (eixo esquerdo) e na indústria de transformação mundial (eixo direito): 1970-2015

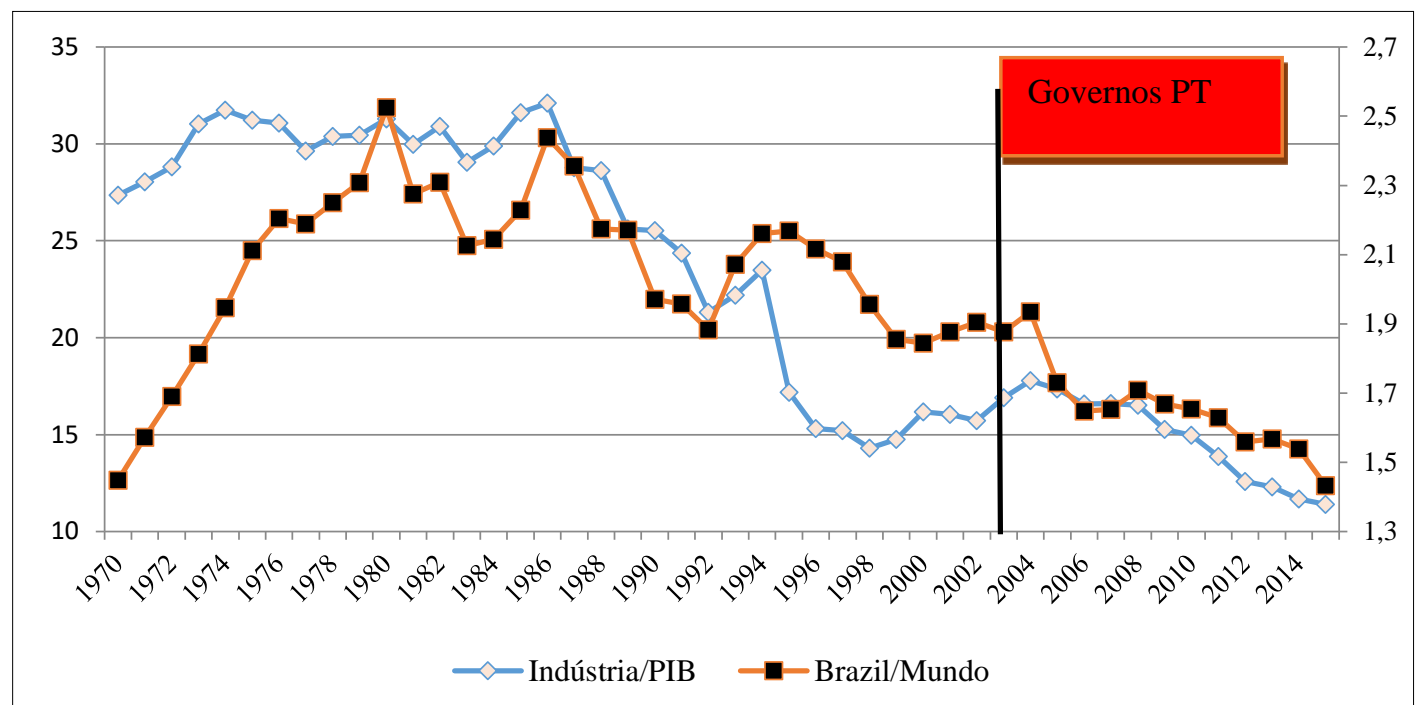

Fonte: UNCTADstat. Elaboração dos autores.

Procurando tornar mais evidente a relativa estagnação do parque manufatureiro do Brasil em termos internacionais, o Gráfico 2 apresenta a taxa acumulada de crescimento da indústria de transformação de inúmeros grupos de países que compõem o sistema econômico internacional. Surpreende o desempenho da indústria brasileira internacionalmente no período dos governos Lula e Rousseff. Os dados revelam que o Brasil apresentou um menor dinamismo industrial no período 2003-2015 não somente em relação à média mundial, mas também em relação ao BRICS, economias em desenvolvimento de alta, média e baixa renda, países islâmicos, países exportadores de petróleo, países árabes, África e África subsaariana, G20, países andinos, América do Sul, países caribenhos, Mercosul e economias industrializadas. O Brasil mostrou, no período 2003-2015, desempenho superior apenas em relação aos países europeus e à Oceania. Portanto, os dados revelam que a relativa estagnação internacional da indústria brasileira durante os governos PT não pode ser atribuída a um eventual "efeito Ásia", argumento de que somente os países asiáticos com mão-de-obra barata, vêm se industrializando e crescendo de maneira acelerada, na contramão do movimento do resto do mundo. Excluindo o "efeito Ásia" da análise, percebe-se que durante os governos do PT o Brasil apresentou, de 
fato, um falling-behind manufatureiro em relação à quase totalidade dos grupos de países que compreendem o sistema mundial ${ }^{1}$.

Gráfico 2

Crescimento acumulado da Indústria de Transformação do Brasil: 2003-2015 (2002=100)

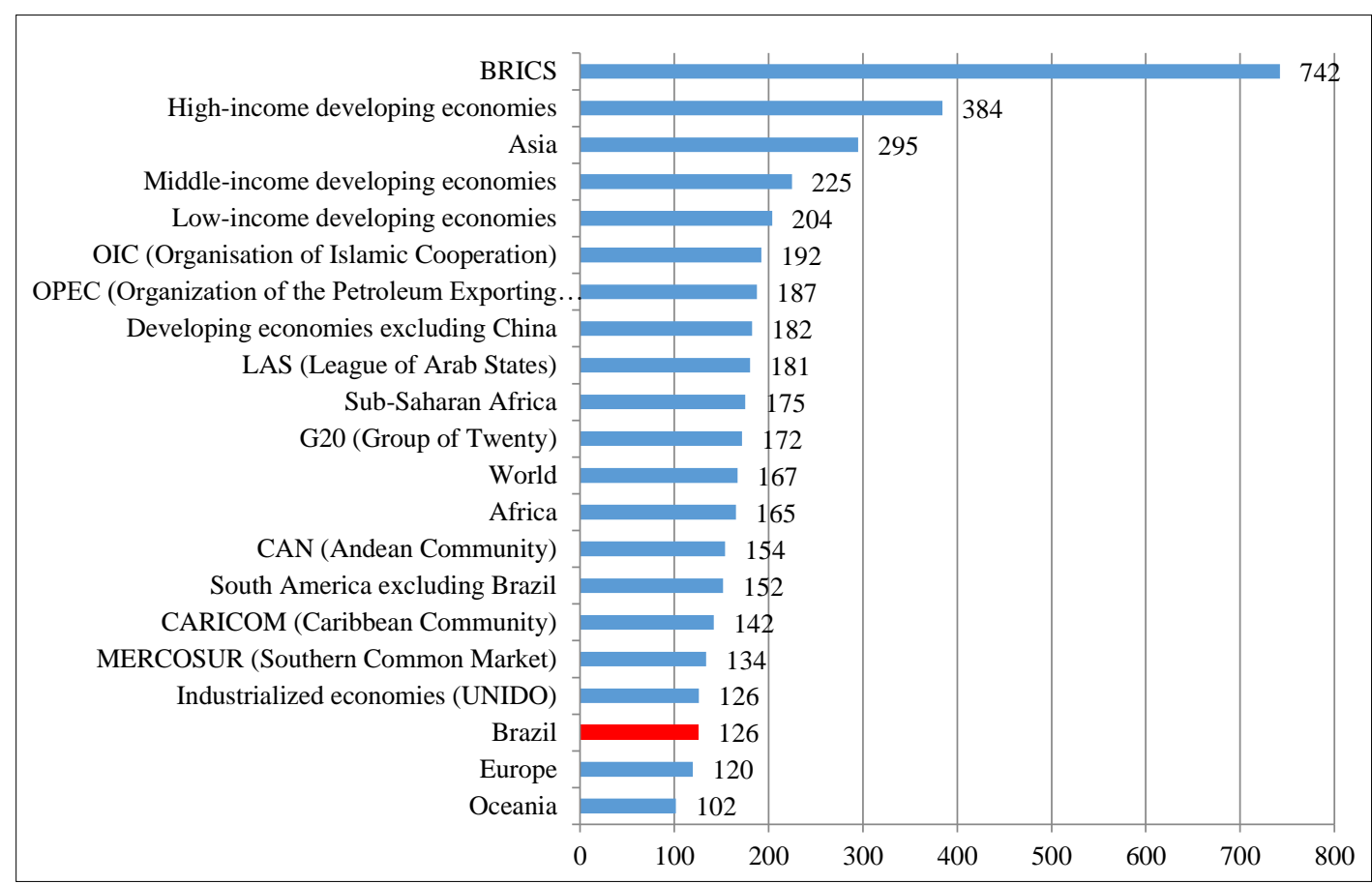

Fonte: Unctadstat. Elaboração dos autores (Valor Adicionado Manufatureiro, em US\$ constantes de 2005).

Já com relação à redistribuição de renda, os governos de Lula e Rousseff não deixam dúvidas quanto a um projeto neste sentido e a seus resultados. Estes ficam evidentes não tanto por sua intensidade - como poderia reclamar o analista mais exigente -, mas principalmente ao se ter presente que o padrão histórico de crescimento do país sempre fora com

(1) O fenômeno da desindustrialização está diretamente relacionado com o crescente peso do setor de serviços nas últimas décadas, no produto e no emprego, tanto em economias avançadas como em desenvolvimento. Todavia, a literatura sobre serviços tem mostrado que a dinâmica de crescimento desse setor tem ocorrido em atividades intensivas em conhecimento e tecnologia que possuem elevada relação com o setor industrial. Os serviços intermediários passaram a fornecer conhecimentos tecnológicos demandados, principalmente, pelas atividades industriais mais sofisticadas. Com isso, parcela considerável das inovações que emergiram a partir da década de 1980 provém dos serviços intermediários e de sua interação com a indústria (Miles et al., 1994, 1995, 2008; Hertog, 2000; Muller; Zenker, 2001; Di Meglio et al., 2015; Dasgupta; Singh, 2007). Nestes termos, processos de mudança estrutural dinâmicos, no século XXI, continuam sendo comandados pelo setor industrial, em co-evolução com serviços avançados. $\mathrm{O}$ atraso da estrutura produtiva brasileira quando comparado com outros países e regiões, também é identificado nos serviços avançados. A tese de Giovanini (2018) mostra que a relação de simbiose entre os setores industrial e de serviços intermediários é praticamente inexistente na economia brasileira, na contramão da dinâmica internacional ocorrida nas últimas décadas. No Brasil, o crescimento do setor de serviços tem ocorrido em atividades tradicionais, intensivas em trabalho e com baixa produtividade. 
aprofundamento da concentração de renda, ou seja, os resultados obtidos dificilmente viriam per si, ou por mera decorrência inerente à lógica dos mercados. Isso pode ser visualizado no Gráfico 3, que mostra a evolução de indicadores relacionados à concentração de renda e à pobreza. Percebe-se claramente uma quebra de tendência a partir de 2003, quando se inicia o primeiro mandato do governo Lula $^{2}$. A partir daí, tanto a concentração de renda quanto a pobreza apresentam queda sustentada.

Gráfico 3

Taxa de pobreza, taxa de pobreza extrema (eixo esquerdo) e Coeficiente de GINI (eixo direito) do Brasil: $1976-2014$

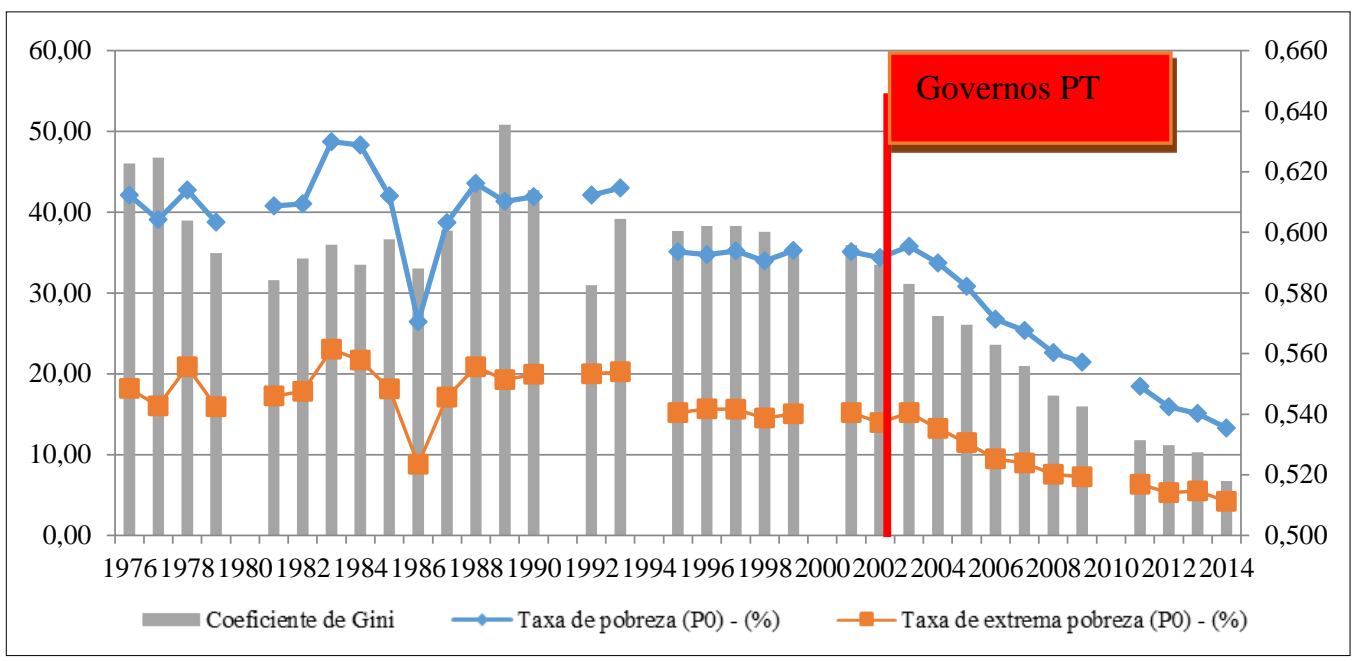

Fonte: Ipeadata. Elaboração dos autores.

Percebe-se que, ao assumir a Presidência da República, Lula, mesmo com ampla aliança, tinha como ponto de honra reverter as desigualdades no país (não só de renda, mas de gênero e raça), mas carecia de um projeto econômico propriamente dito. A rejeição ao neoliberalismo era consenso, mas não o que se poria no lugar dele. Depois de várias derrotas, e disposto a ampliar o leque de alianças, o aceno aos setores empresariais começou com o convite a José Alencar, empresário industrial do ramo têxtil, para ser candidato a vicepresidente. Isso poderia ser interpretado como uma aliança com setores da burguesia local

(2) Estudos recentes vêm criticando o alcance da redistribuição de renda no período, em parte devido a uma questão de dados, pois a queda do coeficiente de Gini é mais nítida quando se utilizam indicadores do mercado de trabalho levantados pela pesquisa por domicílio feita pelo IBGE (PNAD). Tais dados tendem a subestimar a desigualdade de riqueza e outras fontes de renda, como as de natureza financeira. Ver, por exemplo: https://www.oxfam.org.br/sites/default/files/arquivos/Relatorio_A distancia que nos une.pdf

e $\quad$ http://www1.folha.uol.com.br/mercado/2017/09/1921236-desigualdade-no-brasil-e-escolha-politica-diz-economista.shtml. Todavia, cabe ressaltar que apesar da existência de distintas metodologias para a aferição do grau da desigualdade social, o fato é que ocorreu uma forte redução da pobreza a partir de 2003 no Brasil, conforme mostra o gráfico 3. No ano de 2015 o próprio Banco Mundial anunciava que o Brasil praticamente eliminara a pobreza extrema. Ver: https://nacoesunidas.org/relatorio-bancomundial-afirma-que-brasil-conseguiu-praticamente-erradicar-extrema-pobreza/. 
numa agenda pró-produção, industrialista, desenvolvimentista e contrária ao neoliberalismo. Entretanto, a Carta ao Povo Brasileiro viria sinalizar para o oposto, pois o compromisso de manter o tripé da política econômica do governo Cardoso mostrava o reconhecimento à hegemonia do capital financeiro e a disposição de incluí-lo no bloco no poder. Isso significava nada menos que o abandono de bandeiras históricas do PT, como a aversão ao rentismo e a negação das dívidas internas e externa, em relação às quais fizera campanha para serem auditadas. É preciso mencionar que a carta não ficou apenas no plano das intenções nem era vã promessa de candidato, pois a equipe econômica empossada, com forte presença de economistas ortodoxos, a executou à risca, inclusive mantendo a autonomia do Banco Central (por decisão política, já que a Constituição não a assegurava). Com isso, abria-se mão da execução de dois instrumentos indispensáveis para a execução de políticas desenvolvimentistas e para enfrentar o processo de desindustrialização que o Brasil atravessa desde a década de 1980: câmbio e juros - eis duas barreiras intransponíveis para a defesa da existência de um projeto desenvolvimentista no governo Lula, seja no primeiro ou no segundo governo. Assim, não é possível interpretar as taxas de crescimento relativamente altas deste último como resultado de um projeto desenvolvimentista, sendo mais razoável, para tal, a hipótese de uma expansão cíclica posterior a vários anos de baixo crescimento e facilitada pela situação internacional favorável (a demanda chinesa), pela ampliação do crédito às famílias (endividamento) e pelo crescimento real significativo do salário mínimo, com repercussão na expansão da demanda interna de bens de salários e de serviços. O salário mínimo, por servir de indexador a pensões e à previdência social, atuou como fator importante para manter o compromisso histórico de redistribuição de renda e dar ensejo ao que Singer (2012) denominou de "lulismo".

O Gráfico 4 mostra a evolução do salário mínimo (em reais, em dólares a taxa de câmbio vigente no ano e em dólares ajustado pela paridade do poder de compra) e da taxa de desemprego. Percebe-se novamente um ponto de inflexão a partir do início do governo Lula, em 2003, nas quatro variáveis. O salário mínimo no governo Cardoso passou de $\mathrm{R} \$ 70,00$ para $\mathrm{R} \$ 200,00$ entre 1995 e 2002. Já durante os governos do PT, seu crescimento foi robusto e superior aos governos anteriores, atingindo $\mathrm{R} \$ 788,00$ em 2015. Importante destacar a evolução do salário mínimo medido em dólares. A marca de US\$ 100 para o salário mínimo sempre foi emblemática e alcançada durante os governos Cardoso somente em seus anos iniciais, marcados por sobrevalorização cambial. A partir de 2005, essa marca foi novamente ultrapassada, chegando ao seu maior valor histórico no governo Rousseff, US\$ 333,00. Considerando-se o salário mínimo em paridade do poder de compra, seu valor se aproxima de US\$ 400,00 em 2014, evidenciando a melhoria do padrão de consumo conquistada pela classe trabalhadora nos governos PT. Aliado a isso, o gráfico também revela a queda sustentada da taxa de desemprego durante os governos Lula e Rousseff até o final do ano de 2014, quando atingiu seu patamar histórico mínimo de 4,8\%. 
Gráfico 4

Salário Mínimo, em R\$ e US\$ (eixo esquerdo) e Taxa de Desemprego (eixo direito) do Brasil: 1995-2015

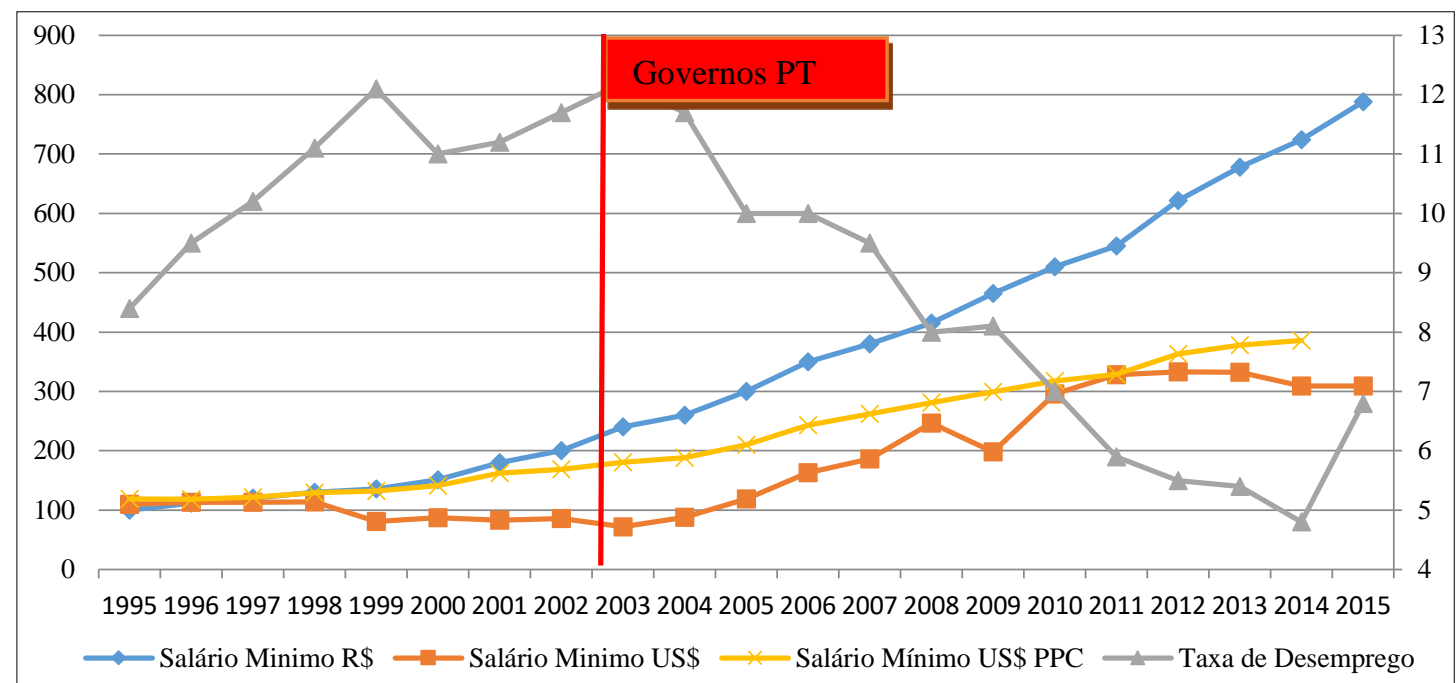

Fonte: Ipeadata. Elaboração dos autores.

OBS: Salário Mínimo em Paridade do Poder de Compra: Fator de conversão que representa, em cada ano, a razão entre os preços ao consumidor de uma mesma cesta de bens no Brasil (em R\$) e nos Estados Unidos (em US\$). A série, calculada em R \$US\$, mostra a taxa observada pelo Banco Mundial em 2011, corrigida pela inflação ao consumidor nos Estados Unidos e no Brasil. Taxas como essa são usadas pelo Banco Mundial em comparações internacionais do consumo agregado das famílias em cada país, assim como na conversão das linhas de pobreza internacionais (em US\$ PPC) para as moedas de cada país.

\section{O governo Rousseff e a "nova matriz" macroeconômica}

Cabe agora abordar o período posterior a agosto de 2011, com a "nova matriz macroeconômica" do governo de Rousseff, já que até então predominara a política semelhante à de Lula. A questão inicial é: faz sentido interpretar a mudança como superação do neoliberalismo e da ortodoxia em favor do desenvolvimentismo? Primeiro, por representar o abandono da política econômica do "tripé" e tentar limitar a autonomia do Banco Central em executá-la, o que é uma alteração de envergadura em sua condução. Segundo, porque boa parte da literatura, já antes mencionada, tanto favorável como crítica às medidas, defende seu caráter desenvolvimentista.

A "nova matriz" não revogou o regime de metas de inflação, mas o flexibilizou; forçou o Banco Central, mesmo quando se antevia inflação crescente, a baixar a taxa de juros e, por conseguinte, a elevar a taxa de câmbio. O Gráfico 5 mostra que a taxa de juros SELIC passou de 12,50\% em agosto de 2011 para 7,25\% no início de 2012, atingindo seu valor real histórico mínimo desde os anos 1980. E, não menos relevante, a taxa de câmbio que era 1,56 R \$/US\$ em agosto de 2011 sofreu desvalorização contínua, chegando a 2,63 R\$/US\$ ao final do primeiro mandato de Rousseff em 2014. É razoável supor que tais medidas combinadas foram percebidas pelo capital financeiro, pelos grandes grupos nacionais internacionalizados e pelas 
corporações não financeiras que aplicavam recursos nos mercados financeiros como quebra de compromisso, principalmente aqueles com passivos em dólar em suas carteiras.

Gráfico 5

Taxa de Juros SELIC (eixo esquerdo) e da Taxa de Câmbio (eixo direito) do Brasil: 2003-2017

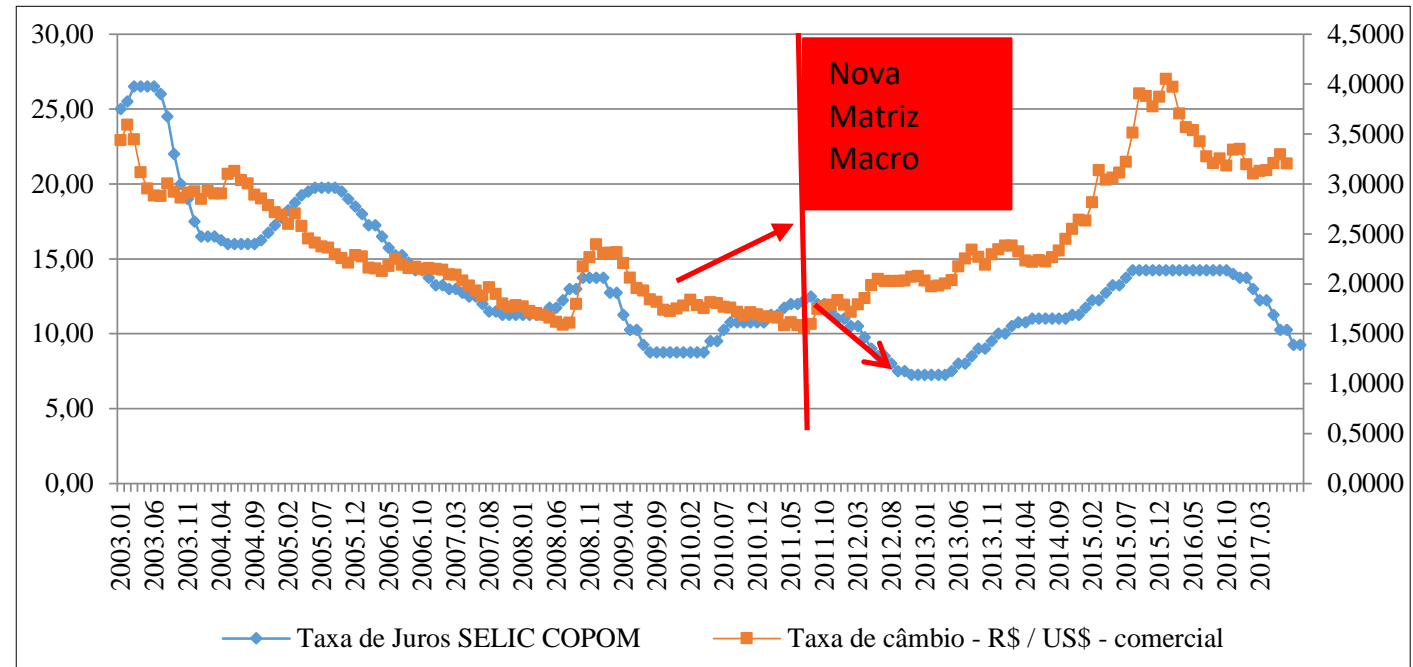

Fonte: Ipeadata. Elaboração dos autores.

Ao mesmo tempo, o BNDES foi estimulado a expandir o crédito e o financiamento para setores específicos da economia através de políticas verticais. Assim, não há dúvida de que o conjunto de medidas da "nova matriz" alterou as diretrizes pétreas firmadas por Lula, da mesma forma que representou um aprofundamento do intervencionismo e se afastou do neoliberalismo, não podendo nem mesmo ser considerado como uma variante deste.

Todavia, embora se possam observar alguns atributos associados ao desenvolvimentismo e se reconheça a reorientação da política econômica no sentido de estimular o crescimento, mais uma vez não vemos bases sólidas para sustentar a hipótese de que se possa falar em desenvolvimentismo. Ao contrário da estratégia de longo prazo que marca o intervencionismo desenvolvimentista, as medidas foram adotadas em reação a uma crise, manifestada pela desaceleração do crescimento, e como forma de enfrentar a conjuntura internacional que começava a reverter o boom das commodities dos anos áureos de Lula.

O Gráfico 6 mostra a evolução dos preços internacionais dos combustíveis e das commodities primárias, bem como a evolução do saldo em transações correntes. Os preços das commodities crescem a partir de 2002 até setembro de 2008, quando ocorre o choque internacional que os reduziu consideravelmente, impactando de forma expressiva as transações correntes da economia brasileira a partir de 2009. No período subsequente, os preços se elevam até meados de 2011, recuando a partir dessa data e encerrando o ciclo do boom das commodities inaugurado no início do século XXI. A queda do preço dessas, a partir de meados de 2011, 
agravou o déficit nas transações correntes, exatamente quando se iniciava a "nova matriz macroeconômica" do governo Rousseff. Certamente esse choque externo exerceu efeitos deletérios na economia brasileira, em razão de seu forte atrelamento à demanda de matériasprimas pela economia chinesa desde o começo dos anos 2000.

\section{Gráfico 6}

Preços Internacionais dos Combustíveis e das Commodities Primárias, exceto Combustível (eixo esquerdo2010=100) Saldo em Transações Correntes, US\$ milhões (eixo direito)

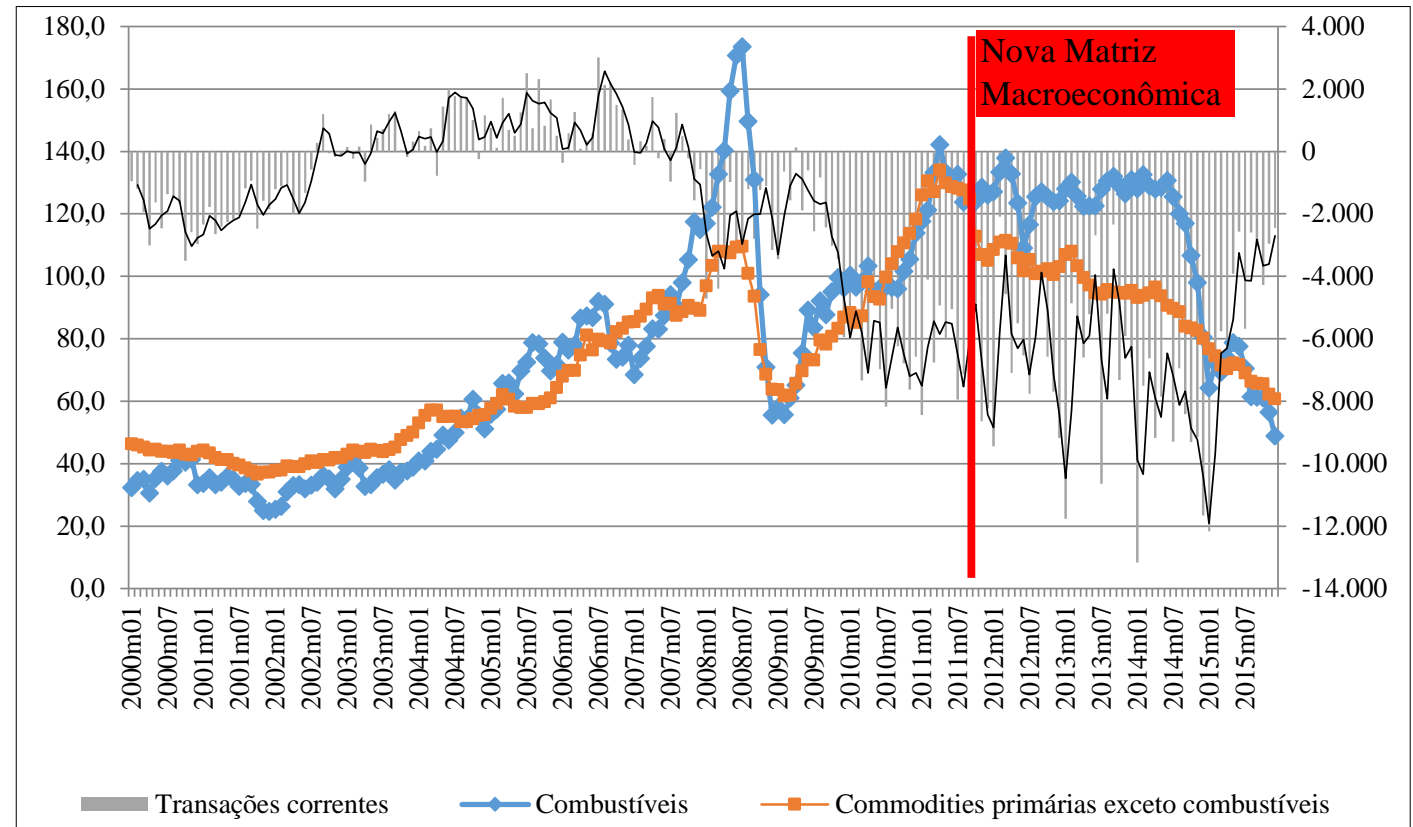

Fonte: CPB Netherlands Bureau of Policy Analysis e Ipeadata. Elaboração dos autores.

Dessa forma, foi essa conjuntura, a partir de 2011, que forçou a pressão do governo para o Banco Central baixar a taxa de juros e desvalorizar o real - duas medidas que são faces de uma mesma moeda, pois juros elevados servem como atrativo para investidores externos, aliviando o balanço de pagamentos através das entradas de capital na Conta Capital e Financeira. Não há dúvida de que medidas como estas poderiam reativar setores industriais tanto devido à mudança de preços relativos favorável à produção doméstica como voltada à exportação - como propõe o Novo-Desenvolvimentismo liderado por Bresser-Pereira (2006, 2016). Entretanto, a desvalorização cambial também impactou negativamente em empresas industriais e financeiras cujos custos dependiam de fornecedores externos, bem como as que estavam endividadas em dólar - prática fartamente usada pela maior parte dos grandes grupos nacionais na época de real valorizado. Assim, a aproximação que a política econômica adotada poderia produzir em relação a alguns setores do empresariado pode ter sido, ao mesmo tempo, o estopim para o afastamento de outros, começando a roer o pacto estabelecido por Lula em 2002. 
O mais importante a salientar, todavia, é que tal alteração da política econômica ocorreu como reação do governo Rousseff à desaceleração cíclica então percebida, e não como uma estratégia desenvolvimentista planejada como tal ${ }^{3}$. Lembra, destarte, mais um conjunto de medidas de caráter keynesiano e de natureza contracíclica do que propriamente desenvolvimentista. Vale salientar que, neste caso, é exigência metodológica que se investigue a motivação ou intencionalidade das políticas econômicas, embora nem neste campo (o das intenções ex-ante) nem dos resultados (ex-post) se pode associá-las a desenvolvimentismo, uma vez que não reverteram nem a desindustrialização, que persistiu no período, e nem mesmo a ativação da demanda agregada aos moldes keynesianos. Esclarecendo: mesmo este caráter "keynesiano" - caso se queira um rótulo - é limitado, tendo em vista que o estímulo governamental se deu muito mais pelo lado da oferta que da demanda (Fonseca, 2016; Paulani, 2017). O governo não apostou primordialmente em gastos públicos (como historicamente procediam os governos brasileiros da "era do desenvolvimentismo"), mas em baixar custos e dar estímulos a grupos privados específicos como forma de estimular o crescimento. Numa espécie de supplysideeconomics, tarifas de energia foram rebaixadas, setores "eleitos" tiveram crédito abundante, impostos diminuídos, isenções e subsídios - o que posteriormente foi pejorativamente denominado "bolsa-empresário". Parece-nos precipitado, como faz Singer (2015, p. 44), entender programas como o "Plano Brasil Maior", que abria linhas de financiamento no BNDES e reduzia o imposto sobre produtos industrializados (IPI) de microempresários, e o programa INOVARAUTO, de proteção à indústria automobilística, como desenvolvimentismo. Ambos, ao contrário, parecem colocar-se mais como respostas à pressão dos próprios setores (tanto dos empresários como dos trabalhadores, ameaçados de perder o emprego). As medidas podem ser defensáveis em contexto de crise, mas não escondem seu caráter "de balcão", ou seja, atendimento de demandas setoriais.

O mínimo que um projeto desenvolvimentista exigiria é que tal intervencionismo partisse de um diagnóstico do baixo crescimento da economia brasileira nas últimas décadas, da especialização regressiva e da desindustrialização, e formulasse uma programação que mostrasse aonde se queria chegar e com que instrumentos. Por exemplo, que apontasse caminhos para favorecer o país a ingressar em novos ramos de maior densidade tecnológica, aos moldes schumpeterianos, de modo a reverter a defasagem da indústria brasileira em setores industriais emblemáticos da revolução tecnológica ancorada na microeletrônica, ou até mesmo que a escolha de "campeões nacionais" fosse relativa a setores emergentes da nova manufatura avançada, ou indústria 4.0. Programas como o INOVARAUTO, ao contrário, lembram

(3) Apenas como comparação: ao contrário dos governos de Vargas, na década de 1930, ou de Geisel, na de 1970, não houve a alteração do "centro dinâmico da economia", como afirma Furtado (1971) com relação ao primeiro, ou "nova mutação" do desenvolvimento, como lembram Castro e Pires (1985) com relação ao segundo. Tais autores deixam claro que as referidas experiências desenvolvimentistas sempre foram marcadas por avanço no processo de industrialização como forma de dar um salto qualitativo no desenvolvimento, indo além da reativação da demanda agregada como resposta a um choque adverso no comércio internacional. 
ironicamente um "nacional-desenvolvimentismo às avessas": apadrinhar uma indústria poluente, multinacional e de onda tecnológica pretérita.

Assim, embora não sejam desprezíveis políticas que vão ao encontro de uma estratégia desenvolvimentista, elas foram setoriais e não podem ser generalizadas. São os casos da indústria naval, do Pré-Sal, dos portos e energia elétrica, setores para os quais se procuraram estabelecem marcos regulatórios com impacto de longo prazo, tanto tecnológicos como institucionais, ao resguardar áreas para o capital nacional e permitir o controle e fiscalização do estado, dentro de uma visão estratégica. Em um tributo à interpretação de Erber (2011) já mencionada, foi nesses setores e nesse momento a única conjuntura em que, de forma mais nítida, a "convenção neodesenvolvimentista" conseguiu impor-se e lograr certo equilíbrio de forças com relação à "institucionalista restrita".

\section{Hegemonia financeira e coalizão de classes: o pacto e sua crise}

Cabe agora procurar responder as duas outras perguntas anteriormente formuladas. Essas indagam sobre os motivos que teriam levado o governo à mudança de política econômica em 2011 e sobre quais setores formavam o bloco no poder dos governos petistas, principalmente que setores do capital os respaldaram ou ajudaram a sustentá-los politicamente e por que os mesmos teriam começado a se afastar no segundo mandato de Rousseff, principalmente a partir de 2011, fato que culminaria no impeachment de Rousseff.

Inicialmente, faz-se necessário mencionar o desafio e a dificuldade metodológica para se detectar classes, frações de classes e setores sociais que constituem o bloco no poder e, dentre essas, qual detém hegemonia, categorias analíticas tributárias a Poulantzas e Gramsci $^{4}$. Em primeiro lugar, porque a política estatal, mesmo que privilegie alguns setores do bloco, também tem um papel mediador, de modo que não exclui outros segmentos que dele não fazem parte. Assim, não há um marco divisório claro, ou critério objetivo, que consiga separar o joio do trigo; se alguns setores se tornam evidentes com poucos dados empíricos, outros ficam em uma zona cinzenta. Elencar um conjunto de medidas do governo para um setor, por exemplo, não significa que o mesmo seja hegemônico e tampouco que participe do bloco no poder, pois o jogo da política é mais complexo em suas formulações e resultados (vale a máxima de que hegemonia significa força e disposição para fazer concessões).

(4) O uso do termo hegemonia, embora se inspire em Gramsci, neste trabalho será utilizado em sentido mais restrito. Para o autor de Quaderni del Cárcere (1975), hegemonia envolve analisar variáveis que fogem ao escopo deste artigo, como o aparato intelectual, a cultura e busca de legitimação através de mecanismos de difusão ideológica. Aqui as categorias "bloco no poder" e "hegemonia" são empregadas de forma semelhante a Poulantzas (1976). O conceito de bloco no poder parte do reconhecimento de "diferenciação interna das classes dominantes" e hegemonia implica a possibilidade de que alguma fração de classe consiga impor seus interesses sobre as demais, ou ter mais poder relativo dentro do referido bloco para fazer valer seus interesses. Ambas as categorias aparecem na passagem: "consegue exercer hegemonia política sobre as outras frações da burguesia e das classes dominantes, isso é, sobre o bloco no poder” (Poulantzas, 1976, p. 37). 
Em segundo, porque as frações burguesas, no capitalismo atual, são bastante misturadas, com portfólio diversificado em vários ramos. Tal diversificação vale também para a classe trabalhadora (que não se confunde com o operariado do século XIX, com novos segmentos de serviços, com exigência de alto conhecimento especializado, setor público, mercado informal, etc.). Assim, enquanto em análises com maior nível de abstração ainda se pode fazer uso de categorias como "capital industrial", "bancário", "agrário" ou "exportador", em estudos históricos concretos é muito mais difícil demarcar a linha divisória entre eles, quando se fala não no capital, mas nos capitalistas que o personificam. Uma vez que as empresas industriais, e não apenas as grandes, possuem aplicações financeiras que dependem de juros reais - o que foi intensificado no Brasil na década de 1980 como forma de proteção de ativos diante da inflação galopante -, medidas como baixar a taxa de juros deixam de ser uma medida consensual para segmentos expressivos do setor ${ }^{5}$. Da mesma forma, conglomerados financeiros têm empreendimentos em agronegócios, de modo que políticas cambiais e monetárias podem impactar de forma diferente de acordo com o segmento envolvido. Em outras palavras, uma pessoa jurídica, ou mesmo um capitalista individual, pode materializar diferentes frações de capital, o que dificulta a demarcação nítida entre frações de classes em estudos de maior concreção, como os que se voltam a perscrutar a associação entre seus interesses de classe e as opções políticas em determinada conjuntura. $\mathrm{O}$ mesmo vale para empresas que produzem simultaneamente para os mercados interno e externo e cujos custos são ao mesmo tempo dolarizados e em moeda nacional, o que, em tese, não as torna em princípio nem a favor de câmbio apreciado nem depreciado, pois o peso de um outro item nos custos varia com a conjuntura.

Isto posto, convém retomar duas interpretações que, de forma mais acabada, enfrentaram tais questões. Ambas convergem ao reconhecer a complexidade de demarcar nitidamente os interesses de frações de classe na sociedade brasileira atual, embora tal dificuldade não signifique impedimento. De um lado, Singer (2015) vê no governo Lula a polaridade entre duas correntes, as quais denomina "rentista" e "produtivista". A primeira abarcaria o capital financeiro e a classe média tradicional, enquanto a segunda abarcaria os empresários industriais associados à fração de classe organizada da classe trabalhadora. Lula seria o árbitro da correlação de forças, "ora dando ganho de causa a uma, ora à outra concorrente". Já a mudança de 2011 de Rousseff é entendida como um "ensaio desenvolvimentista", o qual teria como "a sua marca forte: 'ativismo estatal' na busca da reindustrialização".

Por outro lado, temos os trabalhos de Boito Jr. (2005a, 2005b, 2012) e deste com SaadFilho (Boito Jr.; Saad-Filho, 2016) ${ }^{6}$. Estes, também apoiados em Poulantzas (1978), veem

(5) Ver, nesse sentido, a observação de Epstein (2001, p. 17): "financialization may have changed the structure of class between industry and finance, making their interests much more similar". Especificamente sobre o governo Rousseff, ver Stein (2016).

(6) Ver também dos autores: Boito Jr e Marcelino (2011); Boito (2013); Boito Jr. e Berringer (2014); Saad-Filho e Johnston (2005), Saad-Filho e Mollo (2006), Saad-Filho e Yalman (2009); Saad-Filho e Morais (2014). 
como principal polaridade a existente entre uma burguesia interna e outra mais associada ao capital estrangeiro e, principalmente, ao setor financeiro internacional. Tal como Singer, os autores admitem que a linha divisória entre as frações de classes é tênue, que os dois blocos são compostos por setores diversificados e ressaltam que parte significativa do empresariado sempre evitou se aproximar dos governos petistas. A burguesia interna compreenderia setores tanto industriais como bancos nacionais, o agronegócio e a construção civil, dentre outros. Entretanto, todas as contradições internas desse bloco heterogêneo são tidas como secundárias "frente àquela representada pela disputa com o grande capital internacional" (Boito Jr., 2012, p. 77). A fundamentação dessa tese é bem encorpada, mostrando o apoio de setores da burguesia ao governo Lula através de artigos e depoimentos de líderes da FIESP (como a Revista da Indústria), bem como leis, financiamentos e isenções às empresas do bloco interno, principalmente os "campeões nacionais" do BNDES. Mais prudente que Singer, Boito Jr. (2012, p. 69) trata a política econômica como "neodesenvolvimentista", criando um conceito radial para justificar o "hibridismo"7.

Não cabe aqui avaliar em detalhes a argumentação dos autores, mas assinalar alguns aspectos importantes para o debate, já que ambos o veem como inconcluso e reconhecem a necessidade de mais pesquisas para avançar no tema. Em primeiro lugar, partimos da hipótese de que o PT, em sua formação, propunha ser um partido que expressava os interesses da classe trabalhadora (principalmente sindicalizada), a rigor sem pretensão de representar qualquer fração burguesa. A aproximação com setores empresariais deu-se inicialmente em experiências locais, no governo de Olívio Dutra (1999-2003), no Rio Grande do Sul, assim como em prefeituras (Fontoura, 2015). Contudo, mesmo que ainda se façam necessários mais estudos, admite-se que é difícil defender, no atual "estado da arte", que setores burgueses eram hegemônicos, ou mesmo expressivos, seja no partido ou na formação de tais governos. Todavia, a mudança ocorreu a partir da "Carta ao Povo Brasileiro" (2002). Esta cumpria duas funções, dentre outras: (a) dirigia-se à burguesia como classe, indistintamente, comprometendo-se com o abandono das bandeiras mais radicais do PT no que tange às moratórias e auditorias das dívidas interna e externa, bem como ao direito de propriedade; e (b) acenava particularmente ao setor bancário e a todos os segmentos possuidores de aplicações financeiras, o que compreende não só as grandes empresas, mas as de menor porte, a classe média e até os sindicatos, através dos fundos de pensão (Oliveira, 2003).

Ficava estabelecida, a partir de então, a inclusão da burguesia financeira e dos setores rentistas não só no bloco no poder, mas sua hegemonia. Tal compromisso firmou-se através da manutenção do regime de metas de inflação e do tripé macroeconômico do governo de F. H.

\footnotetext{
(7) Os conceitos radiais são utilizados quando o cientista precisa atualizar o conceito, de forma a ampliá-lo para abarcar fatos novos. Geralmente isso é feito com prefixos ou adjetivos, como seriam os casos de neodesenvolvimentismo, novodesenvolvimentismo, social-desenvolvimentismo, etc. Deve-se ter precaução para que tal "viagem" (traveling) do conceito não ocasione um "alongamento" (stretching) que leve à distorção (Weyland, 2001). Isso ocorre, por exemplo, quando o conceito radial fere o hard-core do conceito original. Neste caso, pode haver um falso positivo, ou seja, o conceito ficaria tão amplo que abarcaria inúmeros casos que, a rigor, não seriam abrangidos pelo conceito original. Por exemplo: qualquer medida intervencionista ou a favor do setor industrial seria considerada como desenvolvimentista.
} 
Cardoso. É esse compromisso que permite falar em hegemonia, pois se trata de políticas decisivas para sua manutenção como a fração mais importante dentro do bloco no poder, e que acabou por levar a joia da coroa: o Banco Central, com a promessa de manter sua autonomia (cabendo sua presidência a Henrique Meirelles, ligado ao PSDB). No marco institucional brasileiro, cabe ao Banco Central, através do Comitê de Política Monetária, a definição das políticas monetárias e cambial. Ao aceitar manter essa regra, o governo Lula abriu mão de parcela significativa da política econômica, restando apenas ao governo propriamente dito, sob sua área de influência, a política fiscal, no Ministério da Fazenda (e uma válvula de escape que será de ora em diante utilizada para compensar os demais segmentos empresariais e os trabalhadores no enfrentamento do setor privado bancário: os bancos públicos).

Deve-se notar que se pode falar em hegemonia porque foi conferida a essa fração de classe, através de dois instrumentos-chave - câmbio e juros - a definição do grau de sua autonomia diante do próprio governo, já que ela se torna capaz de arbitrar ganhos e perdas e, assim, de definir a taxa de lucro não só do setor financeiro, mas de todas as outras frações do capital. Por outro lado, a exigência de superávit primário no tripé impunha limite à única política instrumental que restava ao governo eleito: a fiscal. Deve-se notar que, no Brasil, possivelmente mais do que em qualquer outro país, a hegemonia financeira fica visível ao se perceber que os conceitos de déficit ou superávit nominal do setor público foram abandonados na formulação da política econômica em prol de seus correspondentes "primários"8. Tal conceito difere do déficit ou superávit total por excluir o pagamento de juros e da correção monetária de seu cálculo. Trata-se de um dos principais sustentáculos da hegemonia financeira, pois é uma forma engenhosa de resguardar tais frações do capital de quaisquer medidas de corte de gasto público. A exigência do superávit primário passa a ser a principal tarefa do ministro da Fazenda, e principalmente em momentos de crise, como de inflação alta. Pela regra, comprime-se os gastos dos demais setores, mas resguarda-se o setor financeiro de qualquer ajuste. Além disso, o combate à inflação é feito através dos juros (elevando-os) enquanto ocorrem os cortes orçamentários dos demais setores. Assim, o Banco Central tem autonomia para realizar política exatamente oposta à da austeridade, pois eleva a taxa de juros, o que aumenta os gastos públicos, majora o déficit nominal e neutraliza o esforço da política físcal recessiva. E, o que é mais dramático, torna necessário, num segundo momento, ainda mais cortes "primários", pois o déficit nominal cresce enquanto o superávit primário é perseguido. Nesse aspecto, a "Carta ao Povo Brasileiro", em uma reflexão histórica, lembra outra

(8) A hegemonia financeira não é, obviamente, específica do Brasil. Em outros países também é feito ajuste nos cortes de gastos, inclusive sociais, enquanto os ganhos dos setores rentistas são preservados. No Brasil, entretanto, não só as taxas de juros são bem mais elevadas como a regra do superávit primário como "cláusula pétrea" da política econômica o torna inquestionável e é uma forma para preservar os ganhos financeiros diante de qualquer ajuste. Note-se que se a meta abrangesse o déficit nominal ou total do setor público, o setor financeiro poderia também ser atingido, ou pelo menos objeto de discussão política. Essa preservação e autonomia são exatamente o que sugere o conceito de hegemonia, pois o ajuste é passado adiante para os demais setores sociais, seja do capital ou dos trabalhadores. No limite, e o máximo requinte, deu-se quando a política de impossibilidade de déficit primário foi inserida na Constituição, como ocorreu com a PEC 55, em 2016, proposta pelo governo Temer. Com essa medida, limitou-se mais ainda o alcance do último instrumento de política econômica de todos os governos eleitos nos próximos 20 anos. 
conjuntura brasileira de um governo de esquerda: o parlamentarismo que o presidente Goulart precisou aceitar em 1961, ao qual se submetia e cedia parte do poder para assumir o cargo.

Destarte, parece-nos inapropriada a interpretação de Singer (2015) de que o conflito entre os setores "rentista" e "produtivista" fazia a balança pender entre um e outro, sob a arbitragem de Lula. Não que a correlação de forças não pudesse se alterar ao longo do período, mas por tal interpretação sugerir uma equivalência ou mesmo peso entre ambos no bloco no poder (e, assim, que não havia uma fração hegemônica). Nesse aspecto, nossa análise permite robustecer a hipótese de que a balança sempre pendeu mais para um lado, indo ao encontro de autores que sustentam a participação subordinada do setor produtivista no bloco no poder frente ao capital financeiro, como Paulani (2003; 2017, in: Paula 2005), Teixeira e Pinto (2012), Gonçalves (2012) e Filgueiras (2015). Mesmo a reversão do processo de desindustrialização, que em tese poderia significar maior peso do lado produtivista, não se verificou nem como epicentro da intencionalidade da política econômica (ex-ante) e tampouco em seus resultados (ex-post). Neste ponto, Boito Jr. (2012, p. 69) tem toda razão ao defender que a coalizão governamental aceitava a especialização regressiva, revelando-se, portanto sem projeto para reverter a posição subordinada do Brasil no capitalismo internacional. Já Milan (2017) vai além, pois mostra que nos governos em pauta a inserção externa e a dependência se aprofundaram, portanto, relativizando a força da burguesia interna no bloco no poder.

Nossa interpretação, por conseguinte, é que o governo Lula, ao pactuar com o setor financeiro hegemônico, nunca voltou atrás em tal compromisso (ao ponto de sugerir a Rousseff, em cena de "realpolitik", pouco antes do impeachment, que para evitá-lo a melhor fórmula para "acalmar os mercados" seria convidar Meirelles para comandar a área econômica). Aos demais setores sociais, do capital ou do mundo do trabalho, Lula atendeu com políticas que podemos denominar compensatórias. Assim, a tese central de nossa interpretação sobre a política econômica do governo Lula pode ser expressa como, resguardada a hegemonia do capital financeiro, nacional e internacional, ao outorgar-lhes o epicentro das políticas instrumentais de condução da macroeconomia (como monetárias e cambiais), aos demais segmentos reservaram-se políticas compensatórias - o que não significa que estas, em determinadas conjunturas, possam ser desprezadas ou consideradas menos importantes.

Denominamos aqui de "compensatórias" as medidas tomadas em favor tanto de outras frações do capital como dos trabalhadores (tanto dos sindicalizados da tradicional base petista, como os excluídos do interior profundo do país, contemplados com bolsas e outras políticas públicas). Tal pacto social não pode ser subestimado em sua arquitetura, a qual se apoiava em uma fórmula que previa austeridade macroeconômica conjuntamente com redistribuição de renda - o que fomentava o ceticismo quanto à sua viabilidade. Todavia, o governo a adotou $\mathrm{e}$ manteve as políticas de aumento de salário mínimo e de ampliação de programas como "Fome Zero", "Bolsa Família", "Minha Casa Minha Vida", "Luz para Todos", "Crédito Consignado", "Ciência Sem Fronteiras", "Mais Médicos", assim como a ampliação de vagas em universidades públicas e a adoção do sistema de cotas raciais e por nível de renda. O compromisso histórico com a distribuição de renda e inclusão social foi mantido nos dois 
governos petistas, o que afasta da tentação de considerá-los como neoliberais simplesmente por manterem o tripé macroeconômico e/ou por não terem força política ou disposição para enfrentarem a hegemonia financeira. Como consequência, ao contrário dos governos neoliberais, os programas sociais foram ampliados e o índice de Gini e a taxa de pobreza apresentaram série com melhoria consistente ao longo do período, conforme mostrou o Gráfico 3.

Da mesma forma, entendemos que há respaldo empírico robusto para a interpretação de Boito Jr. (2012) e com Saad-Filho (2016) no que diz respeito à série de medidas em favor dos segmentos "internos" do capital: foram esses setores os mais beneficiados pelas políticas do BNDES, através de crédito, subsídio e isenções. Assim como os bancos nacionais, os quais, mesmo na crise, não viram ameaça nem a seus lucros nem de serem comprados por grupos estrangeiros, como ocorrera no governo Cardoso. Por outro lado, os setores do agronegócio e das empreiteiras nacionais tiveram assegurada sua expansão, inclusive com a política externa de privilegiar eixo Sul-Sul, o Mercosul e o BRICS.

Como se pode então interpretar a "nova matriz macroeconômica" e as mudanças a partir do segundo semestre de 2011? Ora, realmente estas, em primeiro lugar, só podem ser entendidas como reativas à crise e não como decorrentes de projeto de retomar e avançar no processo de industrialização, o que afasta, conforme a conceituação antes adotada, a possibilidade de considerá-las como expressão de uma "virada desenvolvimentista". Mas por que a mudança de orientação? A hipótese fundamental é que a crise internacional, somada às políticas internas de compensação, inviabilizaram a manutenção do pacto estabelecido por Lula. A "fórmula" de conciliação entre classes adotada - austeridade com políticas compensatórias crescentes - supunha, para sua viabilidade, PIB e renda nacional também crescentes. Ela foi possível de ser mantida enquanto houve: (a) folga no balanço de pagamentos, até então assegurada com a os termos de troca favoráveis das commodities e com a disposição de entrada de capitais externos crescentes, seja através de investimentos estrangeiros diretos seja para especulação financeira; (b) espaço para aumento do salário mínimo e dos salários no setor privado, enquanto havia defasagem entre estes e a produtividade, dado o arrocho salarial que vigorara desde o fim da década de 1970; e (c) superávit primário, o que permitiu os gastos públicos e as isenções e subsídios ao capital crescerem sem aumento da carga tributária. Com a queda da produção e o desemprego, o déficit primário não pôde mais ser evitado, frente à maior inelasticidade dos gastos diante das receitas e o fato de algumas destas terem vinculação constitucional, o que acirrou a disputa pelos recursos públicos por parte de todos os segmentos que até então conviviam com razoável civilidade.

O Gráfico 7 mostra que o crescimento do salário mínimo foi muito superior ao da produtividade do trabalho, a qual se manteve estagnada no período dos governos do PT. Essa dinâmica se refletiu em queda de competitividade da indústria brasileira, através da elevação relativa do custo do trabalho, medido em dólares. O aumento contínuo dos salários, aliado à estagnação da produtividade e à taxa de câmbio apreciada, começou a comprimir a taxa de lucro, inviabilizando o investimento. Segundo Marquetti et al. (2017), no governo Dilma 
ocorreu o que na literatura se denomina de "profit squeeze", ou esmagamento dos lucros. Para este autor, com o fim do boom das commodities e a continuidade das políticas de redistribuição de renda, a queda acentuada da taxa de lucro, a partir de 2011, tornou inviável a manutenção do padrão de crescimento do tipo wage-led instituído no governo Lula.

Gráfico 7

Produtividade do trabalho, do salário mínimo e do custo unitário do trabalho no Brasil: 2000-2015 (2000=100)

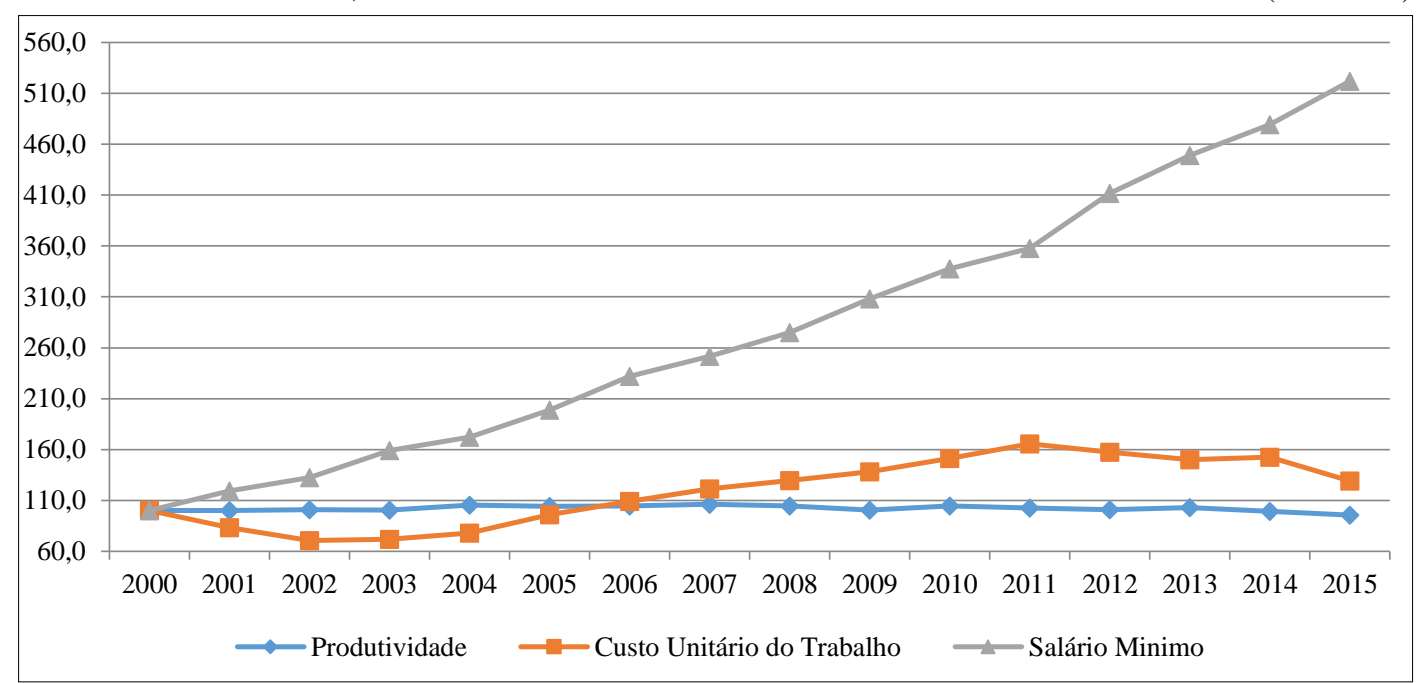

Fonte: Ipeadata e CNI. Elaboração dos autores.

A opção de Rousseff pela mudança, portanto, não resultou de simples escolha, mas de uma imposição dos acontecimentos, pois as bases materiais que sustentavam tal pacto - para usar a velha expressão - não mais existiam. Sua única alternativa para evitar a recessão, e com isso evitar o acirramento das disputas políticas, seria através de uma política anticíclica. A dúvida era: com que instrumentos, já que os mesmos estavam amarrados pelo pacto vigente? Isso só seria possível com o rompimento da coalizão costurada por Lula - o enfrentamento da autonomia do Banco Central e o fim do "tripé" - os quais não eram apenas simbólicos, mas instrumentos indispensáveis como sustentação da hegemonia financeira no bloco no poder. É de notar que, ao fazer tal opção, o governo Rousseff não só atingia em cheio o marco institucional que garantia a hegemonia ao setor financeiro, como afetava também as demais frações burguesas, as quais foram gradualmente se afastando do governo. Na impossibilidade de expandir o déficit público e a carga tributária, o governo optou pelo desastrado "supplyside", ou seja, conceder incentivos para que o próprio investimento privado respondesse pela reativação da economia. Nesse sentido, Carneiro (2017) levanta a questão, que merece ser 
aprofundada, se realmente o estado brasileiro hoje teria instrumentos (empresas públicas, bancos, capacidade de planejamento) para comandar a taxa de crescimento de economia ${ }^{9}$.

Por isso não temos a mesma surpresa de Singer (2015, p. 59), que considera "irônico" os industriais da FIESP terem se alinhado contra o governo enquanto a intervenção atendia, nas palavras do autor, "seus próprios interesses". Poderia se tratar em parte da resistência empresarial ao intervencionismo, assertiva de Kalecki bem lembrada por Rugitsky (2015), mas bem menos da outra razão apontada pelo autor polonês, a referente ao temor de setores privados de que o governo ocupasse seu papel para reverter o ciclo, num embate ideológico: opção diversa desta já fora assumida pela própria política econômica com as medidas pelo lado da oferta.

A título de sugestão, mas que merecem maior investigação, arrolamos vários motivos que teriam contribuído para afastar os setores do empresariado do governo: (a) o déficit público acirrava o conflito dentro dos setores beneficiados pelas políticas compensatórias; os setores empresariais teriam que compartilhar os cortes entre si e com os trabalhadores; (b) o governo sinalizava que não abriria mão de manter os trabalhadores em sua base de apoio. Rousseff, numa expressão bem brasileira, afirmou na campanha da segunda eleição o que vinha fazendo: não mudaria a política de ganhos reais do salário mínimo nem cortes nos programas sociais "nem que a vaca tussa" (https://www.youtube.com/watch?v=hQ9aQo3wjWU). Ou seja: a compressão da taxa de lucro não seria aliviada por queda nos salários - saída classicamente esposada por um governo ortodoxo, que optaria por recessão para enfrentar a crise. A pressão governamental era por expressivos investimentos em produtividade, o que jogava a responsabilidade aos próprios empresários; (c) a alternativa para manter o fluxo de gastos sem aumentar o déficit público só seria viável com aumento de impostos. Os empresários passaram a defender corte de gastos, como a reforma da previdência, enxugamento da máquina pública e nos programas sociais; (d) o risco, diante das alternativas anteriores combinadas, de que o governo optasse por impostos progressivos sobre lucros e propriedade, o que inviabilizaria ainda mais o pacto de coalizão de classes costurado por Lula em 2002; (e) as políticas verticais do governo através de estímulo a "campeões nacionais", isenções de impostos e subsídios atraíam os setores beneficiados, mas ao mesmo tempo desgostavam outros. Os líderes das associações industriais e comerciais, assim, ganhavam apoio dos pequenos e médios empresários desgostosos com a carga tributária e com os custos trabalhistas através de um

(9) Em entrevista para o jornal Folha de São Paulo, em 03/09/2017, Dilma Rousseff, ao ser questionada sobre o insucesso de sua política industrial, afirmou o seguinte: "O que não foi bem correspondido foi a redução de impostos para a indústria. Queríamos trocar desoneração pela manutenção de empregos. O que se provou ali? Que para este setor, no Brasil, a primeira opção é aumentar a margem de lucro. A segunda pode ser aumentar o investimento, mas eu não cheguei a ver essa opção se materializar". Percebe-se que Dilma admite que seu objetivo foi a manutenção do nível de emprego e que sua política "supply side" foi um erro. Todavia, ela atribui seu insucesso ao comportamento dos empresários que procuraram elevar a margem de lucro, quando na verdade os dados mostram que a taxa de lucro estava em queda, e a redução dos impostos apenas compensou a manutenção da margem. Sobre a problemática relativa à queda da taxa de lucro ver Marquetti et al. (2017) e Prado (2017). 
discurso pró-austeridade ${ }^{10}$; (f) os setores internacionalizados somaram-se aos demais para denunciar o intervencionismo, ao verem-se prejudicados com medidas de caráter "nacionalista" em programas como Pré-Sal e indústria naval, que resguardavam parte dos investimentos ao capital nacional. A mídia explorou intensamente que o "nacionaldesenvolvimentismo" de Rousseff nestes setores lembrava o varguismo que F. H. Cardoso prometera em seu governo sepultar para sempre.

Assim, por diferentes motivos, o pacto estabelecido por Lula foi sendo desfeito, unificando todos os segmentos da burguesia contra o governo. Ao assumir no segundo mandato, Rousseff percebeu e montou uma equipe de caráter mais ortodoxo com Joaquim Levy, ligado ao setor financeiro, na pasta da Fazenda. Este retornou ao tripé da política econômica de antes de 2011. Com isso, contrariava a base popular que levara à vitória magra da chapa petista, mas sinalizava que respeitaria os compromissos com o setor financeiro hegemônico. Mas nesta conjuntura, as contradições do governo não eram mais com este setor, pois o Banco Central já recuara na política de juros baixos/câmbio desvalorizado: o crescimento da inflação legitimava a volta da austeridade. O epicentro da discussão da política econômica voltaria ser o superávit primário. Garantida a continuidade da hegemonia financeira, o foco da tensão estava nos setores da política compensatória, com a majoração de incerteza em diversas frentes: que gastos primários seriam cortados? Que impostos seriam aumentados? Os subsídios e isenções aos empresários seriam mantidos? Enfim, sobre quem cairia o custo do ajuste? Deve-se assinalar que enquanto setores empresariais, como a FIESP, já lideravam a campanha do impeachment, o último setor do grande capital a aderi-la foi o financeiro $^{11}$. O que não é de estranhar: o Ministro da Fazenda, Joaquim Levy, saíra de suas hostes e o setor era o único ao qual já estava assegurado, pela própria política econômica vigente, que passaria incólume pela crise. $\mathrm{O}$ único, portanto, ao qual restava certa dose de incerteza quanto ao que poderia perder diante de atitude tão arriscada como a de derrubar um governo eleito.

\section{Conclusão}

Nessa última seção apresentamos uma síntese de nossa interpretação sobre a política econômica dos governos de Lula e Rousseff, bem como de sua base de sustentação. Embora concordemos com a necessidade de dar continuidade às pesquisas e aprofundar as investigações sobre pontos específicos, nossas conclusões preliminares podem ser assim resumidas:

(10) Carneiro (2017, p. 27 argumenta que os financiamentos do BNDES foram muito mais capilarizados, havendo inclusive desconcentração no período. O autor reconhece, entretanto, a "grande publicidade negativa" em torno dos "campeões", e é sobre esta que nos referimos como elemento persuasivo na crítica ao governo.

(11) Ver, nesse sentido: Itaú e Bradesco são contra impeachment de Dilma; http://t.co/3GQfgz4TLe; http://exame.abril.com.br/brasil/presidente-do-itau-unibanco-defende-permanencia-de-dilma/ e https://spotniks.com/7-exemplosde-como-a-elite-brasileira-e-contraria-ao-impeachment-de-dilma/. 
a) O Partido dos Trabalhadores nunca tivera base, desde sua formação, entre setores do empresariado. Na eleição de 2002, o partido passou a defender política de alianças mais amplas, de forma a alargar sua base social e viabilizar sua vitória. Começou com setores da "burguesia interna" (Boito Jr., e Saadi-Filho, 2016) e "produtiva" (Singer, 2012), mas com a "Carta ao Povo Brasileiro" incluiu o setor "rentista" ou financeiro e articulou, assim, um amplo pacto social;

b) A hegemonia, em tal pacto, era assegurada ao capital financeiro (um conjunto de setores não homogêneo e que inclui bancos, investidores externos, fundos de pensão e demais setores possuidores de aplicações financeiras em seu portfólio, como empresários e alta classe média). Mantinha-se, assim, a política econômica do governo Cardoso, assentada no regime de metas de inflação e autonomia do Banco Central para geri-lo, e executada através do tripé formado por altas taxas de juros, câmbio valorizado e superávit primário. Essas medidas, somadas ao fato de não contemplar a reversão da desindustrialização, afastam a possibilidade de entender a política econômica do governo Lula como desenvolvimentista;

c) Os setores não hegemônicos no bloco no poder, ou prejudicados pelas consequências da política macroeconômica implantada, tanto da burguesia como de trabalhadores, seriam contemplados por políticas compensatórias. Essas foram possíveis enquanto houve crescimento do PIB, folga no balanço de pagamentos, defasagem entre salários e produtividade e possibilidade de manter gastos públicos e subsídios sem comprometer o superávit primário;

d) O conjunto das medidas revela que, se o governo Lula (e Rousseff) carecia de um projeto econômico industrializante e desenvolvimentista, por outro lado mantinha seu compromisso com políticas sociais ativas, a fim de reverter as desigualdades sociais e a exclusão social. Assim, a política econômica tampouco pode ser considerada rasamente como expressão de neoliberalismo ou de submissão pura e simples a palavras de ordem como "estado mínimo". Ao contrário, tal pacto político resguardava à fração hegemônica a condução da política macroeconômica, mas exigia intervencionismo permanente para viabilizar e arbitrar as políticas compensatórias;

e) A opção pela "nova matriz macroeconômica" adotada por Rousseff, a partir do segundo semestre de 2011, não foi simples opção de mudança de orientação da política, mas deu-se por pressão da própria crise, com a queda na demanda de commodities, recrudescimento da inflação, diminuição da folga que existia no balanço de pagamentos, no superávit primário e na defasagem entre salários e produtividade. Tratou-se, portanto, não de uma "virada desenvolvimentista", mas de alternativa encontrada para manter o projeto histórico petista de inclusão social, além da consciência de que com políticas recessivas o desfazimento com setores do pacto seria iminente, inclusive com os setores do capital até então beneficiados por políticas compensatórias; 
f) A "nova matriz macroeconômica", portanto, rejeitava a austeridade como forma de enfrentar a crise e o combate à inflação. Mas, para tanto, rompia com o pacto estabelecido por Lula, pois passou a contestar a hegemonia do capital financeiro ao interferir na condução da política macroeconômica adotada e, assim, na autonomia de instrumentos do Banco Central. Entretanto, tal matriz, embora não ortodoxa, tampouco pode ser se considerada, a rigor, decorrente de uma estratégia desenvolvimentista. Esta é mais visível na formulação de marcos regulatórios em alguns setores de infraestrutura, mas mais se assemelha a políticas contracíclicas, seja de caráter keynesiano, de sustentação de demanda agregada, ou pelo lado da oferta, ao pretender assegurar o crescimento com incentivos ao investimento privado;

g) O governo Rousseff procurou, ao iniciar segundo mandato, reestabelecer a hegemonia financeira no bloco no poder. A opção foi por medidas de austeridade e pela volta do tripé macroeconômico. Estas, todavia, acirraram ainda mais o conflito tanto entre os vários segmentos do empresariado entre si como destes com relação aos trabalhadores. Não havia mais condições permissivas para manter o superávit primário juntamente com as políticas compensatórias e a redistribuição de renda, tal como fora possível em 2002;

h) A aliança que sustentou o impeachment manteve a política de austeridade, mas procurou reunificar as frações do capital fazendo os ajustes com a promessa de reformas que excluem segmentos expressivos dos trabalhadores e de parte das classes médias, como reforma trabalhista, teto para os gastos primários, corte de benefícios ao funcionalismo público, liberalização do emprego de trabalhadores terceirizados para qualquer ramo de atividade e reforma da previdência, dentre outras medidas. A definição por busca permanente de ajuste do déficit público através do conceito de superávit primário foi incorporada à Constituição por vinte anos (PEC 55): com isso, procurou-se afastar, por longo período, tentações como a de retorno à "nova matriz" de 2011. Entretanto, as políticas compensatórias já prometidas aos setores empresariais foram asseguradas, como as referentes a subsídios e isenções, e também a recusa ao enfrentamento do déficit pelo lado das receitas tributárias, mantendo sua regressividade. Além disso, ampliaram-se as concessões ao capital internacional e aos setores internos a ele vinculados, como: modificação nas cláusulas do Pré-Sal e da indústria naval, permitindo maior participação de empresas estrangeiras; privatização de aeroportos e na área de energia; e liberalização de áreas protegidas para exploração mineral. A fórmula adotada pelo governo Temer, assim, foi manter a hegemonia do rentismo e tentar recompor o pacto com os setores empresariais que Lula firmara em 2002 e não fora mais possível sustentar a partir de 2011.

\section{Referências bibliográficas}

AGÊNCIA BRASILEIRA DE DESENVOLVIMENTO INDUSTRIAL (ABDI). Plano Brasil Maior. Disponível em: http://www.abdi.com.br/Estudo/Plano\%20Brasil\%20Maior\%20\%20FINAL.pdf. 2011. Acesso em: 11 set. 2017. 
Pedro Cezar Dutra Fonseca, Marcelo Arend, Glaison Augusto Guerrero

ANDERSON, Perry. Lula's Brazil. London Review of Books, v. 5, n. 1, p. 3-12, 2011.

AREND, Marcelo. A industrialização do Brasil ante a nova divisão internacional do trabalho. In: CALIXTRE, André B.; BIANCARELLI, André M.; CINTRA, Marcos Antonio M. Presente e futuro do desenvolvimento brasileiro. Brasília: Ipea, 2014.

ASSIS, José C. A macroeconomia do pleno emprego. In: SICSÚ, João; PAULA, Luiz Fernando R. de; MICHEL, Renaut (Ed.). Novo desenvolvimentismo: um projeto nacional de crescimento com eqüidade social. Barueri: Manole, 2005. p. 77-93.

BASTOS, Pedro P. Z. A economia política do novo-desenvolvimentismo e do social desenvolvimentismo. Economia e Sociedade, 21, p. 779-810, 2012.

BELLUZZO, Luiz G. Um novo estado desenvolvimentista? Le Monde Diplomatique, v. 3, n. 27, p. 4-5, 2009.

BOITO JR., Armando. O Governo Lula e a reforma do neoliberalismo. Revista ADUSP, 34, p. 6-11, 2005a.

BOITO JR., Armando. A burguesia no Governo Lula. Crítica Marxista, 21, p. 52-77, 2005b.

BOITO JR., Armando. Governos Lula: a nova burguesia nacional no poder. In: BOITO JR., Armando; GALVÃO, Andréia (Ed.). Política e classes sociais no Brasil dos anos 2000. São Paulo: Alameda, 2012.

BOITO JR., Armando; SAAD-FILHO, Alfredo. O lulismo é um tipo de bonapartismo? Crítica Marxista, 37, p. 171-181, 2013.

BOITO JR, Armando; SAAD-FILHO, Alfredo. State, state institutions, and political power in Brazil. Latin American Perspectives, v. 43, n. 2, p. 190-206, 2016.

BOITO JR., Armando; BERRINGER, Tatiana. Social classes, neodevelopmentalism, and Brazilian foreign policy under presidents Lula and Dilma. Latin American Perspectives, v. 41, n. 5, p. 94-109, 2014.

BOITO JR., Armando; MARCELINO, Paula. Decline in unionism? An analysis of the new wave of strikes in Brazil. Latin American Perspectives, v. 38, n. 5, p. 62-73, 2011.

BRESSER-PEREIRA, Luiz C. O novo desenvolvimentismo e a ortodoxia convencional. São Paulo em Perspectiva, v. 20, n. 3, p. 5-24, 2006.

BRESSER-PEREIRA, Luiz C. Crônica do novo-desenvolvimentismo e sua macroeconomia estruturalista. 2011. Manuscrito.

BRESSER-PEREIRA, Luiz C. Reflexões sobre o novo desenvolvimentismo e o desenvolvimentismo clássico. Revista de Economia Política, v. 36, n. 2, p. 237-265, 2016.

BRESSER-PEREIRA, Luiz Carlos; NASSIF, André; FEIJÓ, Carmem. A reconstrução da indústria brasileira: a conexão entre o regime macroeconômico e a política industrial. Brazilian 
Journal of Political Economy, v. 36, n. 3, p. 493-513, 2016. (https://dx.doi.org/10.1590/0101$\underline{31572015 \mathrm{v} 36 \mathrm{n} 03 \mathrm{a} 03}$ ).

SILVA, Luiz I. L. Carta aos Brasileiros. Disponível em: http://www1. folha.uol.com.br/folha/brasil/ult96u33908.shtml. Acesso em: 11 set. 2017.

CARVALHO, Fernando C. Lula's government in Brazil: a new left or the old populism? In: ARESTIS Philip; SAAD-FILHO, Alfredo (Ed.). Political economy of Brazil: recent economic performance. London: Palgrave Macmillan, 2007.

CARDOSO JR., José C. Para a reconstrução do desenvolvimento no Brasil: eixos estratégicos e diretrizes de política. São Paulo: Hucitec, 2011.

CARNEIRO, Ricardo. Navegando a contravento (Uma reflexão sobre o experimento desenvolvimentista do Governo Dilma Rousseff). Campinas: Unicamp. IE, 2017. (Texto para Discussão, n. 289).

CASTRO, Antonio. B.; PIRES, S. F. A economia brasileira em marcha forçada. Rio de Janeiro: Paz e Terra, 1985.

CERVO, Amado L. A construção do modelo industrialista brasileiro. Diplomacia Estratégia Política, 10, p. 75-87, 2009.

COSTA, Leila Badeschi. Governo Lula: retorno ao desenvolvimentismo?" Doctoral Thesis. PPGE/UFRGS, 2015.

CURADO, M.; CURADO, T. Uma estimativa dos custos fiscais da política industrial recente (2004 a 2016), Rio de Janeiro, 2016. Disponível em: http://www.ipea.gov.br/portal/index. php?option=com_content\&view=article\&id=29095\&Itemid=1\&fbclid=IwAR1IhFKSWoM0LW21QxELkcnafM3s8xVA3iBGr9qwgonbOui8slCF3SiZUM.

DASGUPTA, S.; SINGH, A. Manufacturing, services and premature deindustrialization in developing countries: a Kaldorian analysis. Advancing Development, Palgrave Macmillan, UK, p. 435-454, 2007.

DI MEGLIO, G. et al. Services in developing economies: a new chance for catching-up? SWPS-32, 2015. Available at SSRN: $\underline{\text { https://ssrn.com/abstract=2744647 }}$ or http://dx.doi.org/10.2139/ssrn.2744647.

EPSTEIN, G. Financialization, rentier interests, and central bank policy. Department of Economics, University of Massachusetts, Amherst, MA, Dec. 2001. Available at: http://goo.gl/IEeSoo.

ERBER, Fabio S. As convenções de desenvolvimento no governo Lula: um ensaio de economia política. Revista de Economia Política, v. 31, n. 1, 2011.

FILGUEIRAS, Luiz. A natureza e os limites do desenvolvimentismo no capitalismo dependente brasileiro. Margem Esquerda, n. 23, 2015. 
Pedro Cezar Dutra Fonseca, Marcelo Arend, Glaison Augusto Guerrero

FONSECA, Pedro C. D. Gênese e precursores do desenvolvimentismo no Brasil. Pesquisa \& Debate, v, 15, n. 2, p. 225-256, 2004.

FONSECA, Pedro C. D. Desenvolvimentismo: a construção do conceito. In: CALIXTRE, André B.; BIANCARELLI André M.; CINTRA, Marcos Antonio M. Presente e futuro do desenvolvimento brasileiro. Brasília: Ipea, 2014.

FONSECA, Pedro C. D. Prejuízo conceitual. Intervencionismo não é sinônimo de desenvolvimentismo. Folha de São Paulo, Caderno Ilustríssima, p. 4-5, 6 mar. 2016.

FONSECA, Pedro C. D.; CUNHA, André M.; BICHARA, Julimar S. O Brasil na era Lula: retorno ao desenvolvimentismo? Nova Economia, v. 23, n. 2, p. 403-428, 2013.

FONTOURA, Leandro H. Reformar à esquerda: a relação de prefeituras petistas com a Administração Pública Gerencial. Tese (Doutorado)-IFCH, UFRGS, 2015.

FURTADO, Celso. Formação econômica do Brasil. São Paulo: Nacional, 1971.

FURTADO, Celso. Criatividade e dependência na civilização industrial. São Paulo: Círculo do Livro, 1978.

GIOVANINI, Adilson. Mudança estrutural no século XXI: a contribuição dos serviços intermediários para o aumento na complexidade econômica. Tese (Doutorado em Economia)Programa de Pós-Graduação em Economia. Universidade Federal de Santa Catarina, 2018.

GONÇALVES, Reinaldo. Governo Lula e o nacional-desenvolvimentismo às avessas. Revista da Sociedade Brasileira de Economia Política, 31, p. 5-30, 2012.

GRAMSCI, Antonio. Quadernidelcarcere. Torino: Einaudi, 1975.

HERRLEIN, Ronaldo. Estado democrático e desenvolvimento no Brasil contemporâneo: um ensaio de economia política. Porto Alegre: Editora UFRGS, 2011.

HERTOG, P. D. Knowledge-intensive business services as co-producers of innovation. International Journal of Innovation Management, v. 4, n. 4, p. 491-528, 2000.

HIRSCHMANN, Albert [1958]. The strategy of economic development. New Haven: Yale University Press, 1964.

KALECKI, Michal. Political aspects of full employment. The Political Quarterly, v. 14, n. 4, p. 322-330, 1943.

MARQUETTI, Adalmir; PORSSE, Mellody de C. S. Patrones de progresso técnico en la economia brasileña, 1952- 2008. Revista da Cepal, n. 113, 2014.

MARQUETTI, Adalmir; HOFF, Cecilia; MIEBACH, Alessandro. Lucratividade e distribuição: a origem econômica da crise política brasileira. In: ENCONTRO NACIONAL DE ECONOMIA POLÍTICA, 22, Campinas, 2017. 
MILAN, Marcelo. Sovereign or dependent integration into the world economy? The Brazilian External Sector, 2017. (Forthcoming).

MILES, Ian et al. Knowledge intensive business services: their roles as users, carriers and sources of innovation. PREST, Manchester, 1994.

MILES, Ian et al. Knowledge-intensive business services: users, carriers and sources of innovation. European Innovation Monitoring System (EIMS) Reports, 1995.

MILES, Ian. Patterns of innovation in service industries. IBM Systems Journal, v. 47, n. 1, p. 115-128, 2008.

MOLLO, Maria de Lourdes R. Por uma dinâmica monetária e financeira menos excludente, In: SICSÚ, João; PAULA Luiz Fernando R. de; MICHEL, Renaut (Ed.). Novo desenvolvimentismo: um projeto nacional de crescimento com equidade social. Barueri: Manole, 2005. p. 401-425.

MORAIS, Lecio; SAAD-FILHO, Alfredo. Da economia política à política econômica: o novodesenvolvimentismo e o governo Lula. Revista de Economia Política, v. 31, n. 4, p. 507-527, 2011.

MULLER, E.; ZENKER, A. Business services as actors of knowledge transformation: the role of KIBS in regional and national innovation systems. Research Policy, v. 30, n. 9, p. 15011516, 2001.

NAKANO, Yoshiaki. Catch up. Folha de São Paulo, 24 jan. 2010.

NOVY, Andreas. O retorno do estado desenvolvimentista no Brasil. Indicadores Econômicos FEE, v. 36, n. 4, p. 121-128, 2009a.

NOVY, Andreas. Política e economia, outra vez articuladas, Le Monde Diplomatique Brasil, v. 3, n. 27, p. 6-7, 2009b.

NUNES, Wellington. Uma estratégia desenvolvimentista sem um 'estado desenvolvimentista': o caso dos Governos Lula. Tese (Doutorado)-Programa de Pós-Graduação em Sociologia, UFPR, 2018.

OLIVEIRA, Francisco de. Crítica à razão dualista: o ornitorrinco. São Paulo: Boitempo, 2003.

PAULA, João. A. Adeus ao desenvolvimentismo: a opção do Governo Lula. Belo Horizonte: Autêntica, 2005.

PAULANI, Leda. Brasil delivery: razões, contradições e limites da política econômica dos primeiros seis meses do governo Lula. In: PAULA, João A. de. A economia política da mudança. Belo Horizonte: Autêntica, 2003.

PAULANI, Leda. Sem esperança de ser país: o governo Lula 18 meses depois. In: SICSÚ, João; PAULA, Luiz Fernando de; MICHEL, Renaut (Ed.). Novo desenvolvimentismo: um projeto nacional de crescimento com equidade social. Barueri: Manole, 2005. p. 49-76. 
Pedro Cezar Dutra Fonseca, Marcelo Arend, Glaison Augusto Guerrero

PAULANI, Leda. The real meaning of the economic policy of Lula's government. In: ARESTIS, Philip; SAAD-FILHO, Alfredo (Ed.). Political economy of Brazil: recent economic performance. London: Palgrave Macmillan, 2007. p. 42-54.

PAULANI, Leda. A experiência brasileira entre 2003 e 2014: neoliberalismo? Cadernos do Desenvolvimento, Centro Internacional Celso Furtado, v. 12, n. 20, 2017.

PERISSINOTTO, Renato. O conceito de Estado desenvolvimentista e sua utilidade para os casos brasileiro e argentino. Rev. Sociologia e Política, v. 22, n. 52, p. 59-75, 2014.

PESSÔA, Samuel. Dominância fiscal, Folha de São Paulo, 11 out. 2015.

PINHEIRO, Armando C.; GIAMBIAGI, Fabio. Rompendo o marasmo: a retomada do desenvolvimento no Brasil. Rio de janeiro: Elsevier/Campus, 2006.

POULANZTAS, Nicos. A crise das ditaduras: Portugal, Grécia e Espanha. Rio de Janeiro: Paz e Terra, 1976.

PRADO, Eleutério F. S. Das explicações para a quase estagnação da economia capitalista no Brasil, Revista de Economia Política, v. 37, n. 3, p. 478-503, 2017.

PREBISCH, Raúl. El falso dilema entre desarrollo económico y estabilidad monetaria. Boletin Económico de America Latina, Cepal, v. 6, n. 1, p. 1-6, 1961.

RUGITSKY, Fernando. Do ensaio desenvolvimentista à austeridade: uma leitura Kaleckiana. 2015. Disponível em: http://jornalggn.com.br/noticia/do-ensaio-desenvolvimentista-aausteridade-por-fernando-rugitsky/. Acesso em: 11 set. 2017.

SAAD-FILHO, Alfredo. Brazil: development strategies and social change from importsubstitution to the 'events of June'. Studies in Political Economy, 94, p. 3-31, 2014.

SAAD-FILHO, Alfredo; BOITO, Armando. Brazil: the failure of the PT and the rise of the 'new right'. In: PANITCH, Leo; ALBO, Greg (Ed.). Socialist register. London: Merlin Press, 2016.

SAAD-FILHO, Alfredo; JOHNSTON, Deborah (Ed.). Neoliberalism: a critical reader. London: Pluto Press, 2005.

SAAD-FILHO, Alfredo; MOLLO, Maria de Lourdes. Neoliberal economic policies in Brazil (1994-2005): Cardoso, Lula, and the need for a democratic alternative. New Political Economy, v. 11, n. 1, p. 99-123, 2006.

SAAD-FILHO, Alfredo; MORAIS, Lecio. Mass protests: Brazilian spring or Brazilian malaise? In: PANITCH, Leo; ALBO, Greg; CHIBBER, Vivek (Ed.). Socialist register. London: Merlin Press. 2014. p. 227-246.

SAAD-FILHO, Alfredo; YALMAN, Galip. Economic transitions to neoliberalism in middleincome countries. London: Routledge, 2009. 
SARTORI, Giovanni. Concept misformation in comparative politics, American Political Science Review, 64, p. 1.033-1.053, 1970.

SARTORI, Giovanni. Guidelines for concept analysis. In: SARTORI, Giovanni (Ed.). Social science concepts: a systematic analysis. Beverly Hills: Sage, 1984. p. 15-85.

SCHAPIRO, Mario G. Ativismo estatal e industrialismo defensivo: instrumentos e capacidades na política industrial brasileira. Brasília: IPEA, 2013. (Texto para Discussão, n. 1856).

STEIN, Alexandre de Queiroz. Desenvolvimentismo no primeiro Governo Dilma: intencionalidade, capacidades políticas e financeirização. Monografia (Graduação)-FCE/ UFRGS, 2016.

SINGER, André. Os sentidos do Lulismo: reforma gradual e pacto conservador. São Paulo: Cia. das Letras, 2012.

SINGER, André. Cutucando onças com varas curtas: o ensaio desenvolvimentista no primeiro mandato de Dilma Rousseff (2011-2014). Novos Estudos, 102, p. 39-67, 2015.

STUMM, M; NUNES, W; PERISSINOTTO, R. Ideias, instituições e coalizões: as razões do fracasso da política industrial lulista. Brazilian Journal of Political Economy, v. 39, n. 4, p. 736-754, out./dez. 2019. (https://dx.doi.org/10.1590/0101-31572019-2978).

TEIXEIRA, Rodrigo A.; PINTO, Eduardo C. A economia política dos governos FHC, Lula e Dilma: dominância financeira, bloco no poder e desenvolvimento econômico. Economia e Sociedade, 21, p. 909-941, 2012.

WEYLAND, Kurt. Clarifying a contested concept; populism in the study of Latin American politics. Comparative Politics, v. 34, n. 1, p. 1-22, 2001. 